\title{
Thalamic NMDA Receptor Function Is Necessary for Patterning of the Thalamocortical Somatosensory Map and for Sensorimotor Behaviors
}

\author{
Hiroyuki Arakawa, ${ }^{1}$ Ayumi Suzuki, ${ }^{2,3}$ Shuxin Zhao, ${ }^{1}$ ○Vassiliy Tsytsarev, ${ }^{1}$ Fu-Sun Lo, ${ }^{1}$ Yu Hayashi, ${ }^{4}$ \\ Shigeyoshi Itohara, ${ }^{4}$ Takuji Iwasato, ${ }^{2,3}$ and Reha S. Erzurumlu ${ }^{1}$ \\ ${ }^{1}$ Departments of Anatomy and Neurobiology, University of Maryland School of Medicine, Baltimore, Maryland 21201, ${ }^{2}$ Division of Neurogenetics, National \\ Institute of Genetics (NIG) and ${ }^{3}$ Department of Genetics, SOKENDAI, Mishima, Shizuoka 411-8540, Japan, and ${ }^{4}$ RIKEN Brain Science Institute (BSI), \\ Wako, Saitama 351-198, Japan
}

\begin{abstract}
NMDARs play a major role in patterning of topographic sensory maps in the brain. Genetic knock-out of the essential subunit of NMDARs in excitatory cortical neurons prevents whisker-specific neural pattern formation in the barrel cortex. To determine the role of NMDARs en route to the cortex, we generated sensory thalamus-specific NR1 (Grin1)-null mice (ThNR1K0). A multipronged approach, using histology, electrophysiology, optical imaging, and behavioral testing revealed that, in these mice, whisker patterns develop in the trigeminal brainstem but do not develop in the somatosensory thalamus. Subsequently, there is no barrel formation in the neocortex yet a partial afferent patterning develops. Whisker stimulation evokes weak cortical activity and presynaptic neurotransmitter release probability is also affected. We found several behavioral deficits in tasks, ranging from sensorimotor to social and cognitive. Collectively, these results show that thalamic NMDARs play a critical role in the patterning of the somatosensory thalamic and cortical maps and their impairment may lead to pronounced behavioral defects.
\end{abstract}

Key words: barrel cortex imaging; barreloids; barrels; glutamate; pattern formation

\section{Introduction}

Neural maps of the sensory receptor surface form at many levels of the CNS during development. These maps are often patterned in ways that reflect specialization of the sensory periphery, and they are crucial for functional maturation of the system. Several molecular guidance cues and glutamatergic neural transmission play critical roles in development of sensory brain maps (Erzurumlu and Gaspar, 2012).

The whisker/barrel system in mice is an excellent model to investigate the cellular and molecular bases of neural pattern formation and plasticity in mammalian sensory systems. At all three levels of the trigeminal pathway [the principal sensory nucleus of the trigeminal nerve $(\mathrm{PrV})$, in the brainstem, ventrobasal (VB) nucleus in the thalamus, and primary somatosensory (SI) or "barrel cortex"), presynaptic afferent terminals replicate the pat-

Received April 24, 2014; revised July 22, 2014; accepted July 24, 2014.

Author contributions: H.A., A.S., V.T., F.-S.L., Y.H., S.I., T.I., and R.S.E. designed research; H.A., A.S., S.Z., V.T., F.-S.L., Y.H., S.I., and R.S.E. performed research; H.A., A.S., S.Z., V.T., F.-S.L., Y.H., S.I., and R.S.E. analyzed data; T.I. and R.S.E. wrote the paper.

A.S. was supported by the Japan Society for the Promotion of Science. This work was supported by FIRST program to S.I., KAKENHI (22115009) and Naito Foundation to T.I., and National Institutes of Health grants NSO39050 and NS037070 to R.S.E. We thank Y.M. Saito and RIKEN BSI Research Resource Center for their help with generation of the 5HTTCre mice and $\mathrm{K}$. Arakawa for breeding and genotyping mice at UMB.

The authors declare no competing financial interests.

Correspondence should be addressed to Dr. Reha S. Erzurumlu, Departments of Anatomy and Neurobiology, UMB SOM, 20 Penn Street HSFII S251, Baltimore, MD 21201. E-mail: rerzu001@umaryland.edu.

DOI:10.1523/JNEUROSCI.1663-14.2014

Copyright $\odot 2014$ the authors $\quad 0270-6474 / 14 / 3412001-14 \$ 15.00 / 0$ terned distribution of whiskers on the snout. The presynaptic patterns are recognized by postsynaptic neurons, which, in turn, form rings or neural modules around afferent terminals. The neuronal patterns are called "barrelettes" in the PrV, "barreloids" in the VB, and "barrels" in the SI cortex. NMDARs play a key role in the formation of these maps through their special property of detecting and signaling correlated activity of incoming sensory afferent inputs (Erzurumlu and Kind, 2001; Ruthazer and Cline, 2004; Erzurumlu and Iwasato, 2006).

The thalamic barreloids appear a day or two after barrelette formation in the brainstem (Erzurumlu and Gaspar, 2012). However, a prolonged synaptic refinement continues over a two-week period at the lemniscal thalamic synapse in the VB (Arsenault and Zhang, 2006). NMDARs play a key role in glutamatergic transmission in the developing VB, as in other sensory thalamic nuclei. A notable shift from predominantly NR2Bcontaining NMDARs to NR2A-containing NMDARs has been noted during the first 2 weeks of life in the mouse VB and somatosensory cortex (Liu et al., 2004). A recent study using genetic mosaic deletion of NMDARs showed that pruning and strengthening of immature lemniscal synapses in the VB fails to take place in neurons without functional NMDARs, but occurs in neighboring neurons with intact NMDARs (Zhang et al., 2013). However, the role of postsynaptic NMDARs of VB neurons in pattern formation and thalamocortical communication has not been studied in detail. Here, we investigated how genetic elimination of NMDAR function in the VB affects barreloid and barrel devel- 
opment, thalamocortical transmission of information, and, ultimately, sensorimotor and cognitive function.

\section{Materials and Methods}

\section{Generation of 5-HTTCre Tg mice}

The 5-HTTCre Tg construct was created by modifying the RP23-39F11 BAC clone (Mizuno et al., 2014), derived from C57BL/6 (B6) mouse genomic DNA. The nuclear localization signal (NLS) Cre-pA cassette (Iwasato et al., 2000) was excised with KpnI/SalI and inserted into the SpeI site of the pS120 vector (Iwasato et al., 2007) by blunt-end ligation. The NLS-Cre-pA-FRT-Amp-FRT sequence in the resulting construct was amplified with the primer pair 5'-AGAACCAAGAGCTAG TCAGGGTCCTTGGCAGATGGGCATCCGCACCACTGACTGACTC GACCTGCAGCCCAAGCTGTAC-3' and 5' -CTTGGCAGTCCTCT TTGTCCTTACACTCTGACAGCACTTTCTGAGAATTCAAAGGTCCTTGACCAAGTTGCTGAAG-3' and was processed for BAC recombination with the Red/ET system (Gene Bridges). The Amp sequence in the obtained BAC construct was removed by flp/FRT recombination in bacteria. The $\mathrm{Tg}$ founder mice were generated by microinjection of linearized constructs into B6 fertilized eggs and maintained in a B6 genetic background.

\section{Animals}

All animal handling was in accordance with the National Institutes of Health Guide for the Care and Use of Laboratory Animals (NIH Publications No. 80-23) revised 1996, a protocol approved by the University of Maryland, Baltimore (UMB) Animal Use and Care Committee; and guidelines for animal experimentation of the National Institute of Genetics (NIG) and RIKEN Brain Science Institute (BSI). 5-HTTCre Tg mice were generated at the RIKEN BSI, and colonies set up at UMB and NIG. ThNR1KO mice were generated using 5-HTTCre Tg, NR1 ${ }^{+/-}$ mouse (Li et al., 1994) and floxed NR1 mouse (Tsien et al., 1996) lines. Genotypes were determined by PCR from tail DNA samples with primer sets: CW-Cre2 (5'-ACC TGA TGG ACA TGT TCA GGG ATC G-3')/ CW-Cre3 (5'-TCC GGT TAT TCA ACT TGC ACC ATG C-3') for 5-HTTCre mouse; TI-NR1-X2 (5' -ATG ATG GGA GAG CTG CTC AG$\left.3^{\prime}\right) /$ TI-Prpgk-3 (5' -CAG ACT GCC TTG GGA AAA GC-3') for NR1 ${ }^{+/-}$ mouse; NR1ER5 ( $5^{\prime}$-TGT GCT GGG TGT GAG GGT TG-3')/NR1ER10 ( $5^{\prime}$-GTG AGC TGC ACT TCC AGA AG-3') for NR1 ${ }^{\mathrm{f} / \mathrm{f}}$ mouse; KS68 (5' ${ }^{\prime}$-TTCTCGTTGGGGTCTTTGCT-3')/KS69 (5' -ACTTCTTCAAGTC CGCCATG-3') for TCA-GFP mouse (Mizuno et al., 2014); R1295 (5'-GCGAAGAGTTTGTCCTCAACC-3'/R523 (5' -GGAGCGGGAGAA ATGGATATG-3')/R26F2 ( (' $^{\prime}$-AAAGTCGCTCTGAGTTGTTAT-3') for Rosa-NLS-LacZ (RNZ) reporter mice (Kobayashi et al., 2013); $5^{\prime}$-TCGGCGGTGAAATTATCGATGAGC-3'/5' -CCACAGCGGATG GTTCGGATAATGC-3' for CAG-CAT-Z reporter (CCZ) mouse (Sakai and Miyazaki, 1997).

CCZ and RNZ reporter mice were backcrossed into B6 genetic background more than six and three generations, respectively. NR1 ${ }^{+/-}$and $\mathrm{NR} 1{ }^{\mathrm{f} / \mathrm{f}}$ mice were backcrossed into $\mathrm{B} 6$ genetic background more than 20 generations. 5-HTTCre and TCA-GFP mice had pure B6 genetic background.

\section{Histology and immunohistochemistry}

Morphological studies were performed in our laboratories in Mishima, Japan and Baltimore, Maryland. For these studies, we used 5-HTTCre; NR1 $1^{\text {flox/- }}$ (ThNR1KO) and control (5-HTT-Cre;NR1 $1^{\text {flox } /+}, \mathrm{NR} 1^{\text {flox } /-}$ alone or NR1 $1^{\text {flox/++}}$ ) mice of either sex between P3 and P14. For cytochrome oxidase (CO) histochemistry, two KO and nine control P7 mice (Japan); four to six each P3, P5, P7, and P9 KO; and control mice were analyzed. For Nissl staining, three KO and four control P7 mice (Japan) and two to six each $\mathrm{KO}$ and control mice at P3, P5, P7, and P9 were used. TCA terminal patterning in control TCA-GFP and ThNR1KO;TCA-GFP mice were analyzed at P7, $n=5$ and 2, respectively, in Japan. Cremediated recombination was analyzed in 5-HTTCre Tg mice crossed with RNZ reporter mice in Japan and for these studies E15, E17, P0, P5, P7, and P38 mice were used. Immunohistochemistry for VGLUT2, 5-HTT, NeuN, Cux-1, and NMDAR1 were done on sections derived from the brains of $>20 \mathrm{KO}$ and control mice at P3, P5, P7, P9, and adult in the United States.

$\mathrm{CO}$, Nissl, and LacZ staining were performed as previously described (Iwasato et al., 2000). For $\beta$-galactosidase/NeuN double immunohistochemistry, 4\% PFA in $0.1 \mathrm{M}$ PB fixed brains were sectioned frozen. Mouse anti-NeuN monoclonal (1:100; Millipore Bioscience Research Reagents MAB377), rabbit anti- $\beta$-galactosidase polyclonal (1:10,000; Cappel 55976), anti-mouse IgG-Alexa488 (1: 500; Invitrogen), and anti-rabbit IgG-Alexa546 (1:500; Invitrogen) antibodies were used. We performed double immunostaining using antibodies against NeuN and Cux-1 for neuronal labeling, VGLUT2, and serotonin transporter (5-HTT) antibody for afferent terminals in the VB and the barrel cortex. The primary antibodies were rabbit polyclonal 5-HTT antibody (Ab) (1:5000; Calbiochem), guinea pig polyclonal Ab VGLUT2 (1:2000; Millipore Bioscience), mouse monoclonal $\mathrm{Ab} \mathrm{NeuN}$ (1:500; Millipore Bioscience), and rabbit polyclonal Cux-1 (1:2000; Sigma). Additionally, we used mouse anti-NR1 antibody (1:500; BD PharMingen).

\section{Brain slice preparations and electrophysiology}

Mice were anesthetized by isoflurane and decapitated. The brains were removed and immersed in cold $\left(4^{\circ} \mathrm{C}\right)$ artificial CSF (ACSF). Thalamocortical slices (400 $\mu \mathrm{m}$; Agmon and Connors, 1992; Lee et al., 2005a) and horizontal thalamic slices ( $400 \mu \mathrm{m}$; Castro-Alamancos, 2002; Kivrak and Erzurumlu, 2013) were incubated in ACSF at $33^{\circ} \mathrm{C}$ before transferring into the recording chamber. During electrophysiological recording, we added $50 \mu \mathrm{m}$ picrotoxin to the ACSF to block GABAergic responses.

Whole-cell-patch recordings were done, as described previously (Lo et al., 2013). After forming whole-cell configuration in thalamocortical slice experiments, depolarizing current pulses were passed through the patch pipette to identify firing pattern of excitatory neurons in currentclamp mode. A concentric stimulating electrode (WPI; TM33CCINS) was inserted into the VB. Electrical pulses $(0.3 \mathrm{~ms}$ duration, $0.2 \mathrm{~Hz})$ were passed through the electrode to evoke excitatory postsynaptic responses in both current- and voltage-clamp mode. Paired pulses at an interval of $200 \mathrm{~ms}$ were delivered to test the paired-pulse ratio (PPR) of layer 4 neurons. For thalamic experiments, VB neurons were identified by a low-threshold spike (LTS), mediated by T-type $\mathrm{Ca}^{2+}$ channels, after sudden release from hyperpolarization. Postsynaptic responses were induced by stimulation of the medial lemniscus (Lem).

We recorded from 15 control, 8 ThNR1KO VB, and 15 control, $9 \mathrm{KO}$ layer 4 barrel cortex cells in slices derived from 10 control (5-HTT-Cre; NR1 $1^{\text {flox/+ }}$, NR $1^{\text {flox } /-}$ alone or NR1 $1^{\text {flox } /+}$ ) and 5 ThNR1KO 2- to 4 -weekold mice of either sex. All biological data were acquired by an InstruTECH ITC-16 Data Acquisition Interface unit and stored on a Dell DM061 computer with PULSE (HEKA) software program. All data are expressed by mean \pm SE and a Student's $t$ test was used.

\section{Optical imaging}

Experiments were performed on ThNR1KO $(n=6)$ and control (NR ${ }^{\text {flox/flox }}, n=6$ ) male and female mice at $4-5$ weeks of age using the MiCAM02 system (Brain Vision). Animals were anesthetized with urethane $(1.5 \mathrm{~g} / \mathrm{kg}$ body weight $)$, and after shaving their heads, they were placed into a stereotaxic frame. A $3 \times 3 \mathrm{~mm}$ cranial opening was made over the left parietal cortex. The exposed surface of the dura mater was cleaned with hemostatic sponges dipped in ACSF. The voltage-sensitive dye RH-1691 (Optical Imaging; $1.0 \mathrm{mg} / \mathrm{ml}$ in ACSF) was applied to the surface of the dura mater for $45 \mathrm{~min}$. After that the cortex was washed with dye-free ACSF for 15 min (Tsytsarev et al., 2010; Lo et al., 2013; Tominaga et al., 2013). The cortical surface was covered with highdensity silicone oil and then sealed with a $0.1-\mathrm{mm}$-thick cover glass to suppress the brain pulsation originating from cardiovascular and respiratory movements (Lo et al., 2013). The objective of the imaging system was positioned above the recording area with its optical axis perpendicular to the imaging surface. The focusing plane was adjusted to the depth of $300 \mu \mathrm{m}$ below the cortical surface. At the start of each optical recording, a grayscale image of the cortical surface was obtained. Each experimental session consisted of 100 trials, 500 frames per trial, with the stimulus (whisker $\mathrm{C} 2$ deflection) presented at the 300th frame, 1 trial per stimulus. The intertrial interval was $12 \mathrm{~s}$. Change in fluorescence was calculated as $\Delta F / F$ in the ROI using Brain Vision Analyzer. 
Before whisker stimulation, all of the whiskers, except the C2 or the E2 whisker, were clipped close to the skin. A glass pipette $(1.0 \mathrm{~mm}$ in diameter) fitted onto an XYZ manipulator was aimed at the C2 whisker and air-puff stimulus of $10 \mathrm{~ms}$ duration was applied through a Picospritzer pressure valve connected to the glass pipette. The Picospritzer was coupled to the imaging system through the MiCAM02 computer so that the air could be puffed onto the whiskers and optical signals collected simultaneously. For data analysis, we constructed a pseudocolor map using first-frame analysis and then averaging the data for each session (Ferezou et al., 2006; Tsytsarev et al., 2010), and obtained pseudocolor maps of the whisker stimulation activated cortical areas.

\section{Behavioral tests}

We used a battery of sensorimotor and cognitive social behavior tests to evaluate the performance of mice with NMDAR genetic loss of function in the sensory thalamus. Whisker sensation-related tests were specifically chosen or devised based on our previous experience that B6 mice perform poorly in these tests when their whiskers are clipped bilaterally.

For behavioral testing we recorded the performance of ThNR1KO $(n=8)$ and control (NR1 $\left.{ }^{\text {flox/flox }}, n=8\right)$ adult male mice. Mice were single housed in standard shoebox cages for 1 week before the start of testing. They received water and standard rodent chow. The mice were housed in a room that was environmentally controlled on a 12:12 h light/dark cycle (06:00-18:00 h lighting) at a temperature of $21^{\circ} \mathrm{C}$, relative humidity of $50-60 \%$. On each testing day, mice were moved to the experimental room and left undisturbed for $30 \mathrm{~min}$ before testing. Testing was done in tandem with small groups of mice. We ran three cohorts of animals (first, $\mathrm{KO} n=3$, control $n=3$; second, $\mathrm{KO} n=2$, control $n=$ 3; third KO $n=3$, control $n=2$ ) at different times. The genotypes of animals were blind to the behavioral tester throughout the experiment and analysis.

Statistical analysis. In the case of comparison between genotypes (ThNR1KO vs NR1 $1^{\text {flox/flox }}$ ), unpaired two-tailed Student's $t$ test was used. Two-way ANOVA with genotype and trial factors or genotype and whisking type factors were used to analyze the behavioral data (bridgewalking test, whisking frequencies, object recognition, and texture discrimination). Bonferroni post hoc comparisons were used with significant ANOVAs. Results were considered significant when $p<0.05$.

The gap-crossing test (Hutson and Masterton, 1986), adapted to mice by Barnéoud et al. (1991), is a specific test for cortical whisker function. This test was conducted under light and dark (infrared light) conditions.

The edge-approach test is principally based on the postural reflex and limb placement tests (Gerlai et al., 2000). Mice were picked up by the tail manually, and then slowly lowered toward a flat edge of the table $(1 \mathrm{~cm} / 5 \mathrm{~s})$. The procedure was repeated four times and the distance of their body position from the edge of the platform that they were able to reach was measured.

In the sticky paper test, a small piece of sticky paper tape $\left(1 \mathrm{~cm}^{2}\right)$ was applied to the plantar surface of the hindpaw and the mouse was allowed to move freely around the home cage. The latency of the first reaction to the paper was measured. This test was used for assessing paw sensorimotor responses.

The grid-walking test was also conducted to assess paw sensorimotor performance (Cummings et al., 2007). Mice were placed on the stainless grid (4 mm diameter, $1 \mathrm{~cm}$ distance) and allowed to walk around for 3 min. Their performance in walking across the grid was recorded for each paw making 20 steps. The ratio of correct steps for each paw was calculated as a correct step ratio.

The bridge-walking test was conducted in three trials for each mouse. Each mouse was placed on the edge of a $25 \mathrm{~cm}$ runway $(4 \mathrm{~cm}$ wide and 15 $\mathrm{cm}$ height) connected to a platform. The latency to reach the platform was recorded on each of the three trials (a maximum cutoff time was $180 \mathrm{~s})$.

The wire hanging test was used as a measure of grasping strength and motor performance. The hindlimbs of the mouse were taped so that the mouse used its forelimbs to suspend its body on a wire line. The mean time to suspend the body was recorded from three trials.

Whisking was observed at high speed (120 fps) with a high-speed camera (FX-FH100; Casio). Each mouse was allowed to investigate a small clear plastic cup for $3 \mathrm{~min}$. The frequencies and the types of whisking were quantified.

The object-shape recognition task was conducted for three trials in the home cages under red light illumination. During the first trial, two objects were placed in opposite corners of the home cage, and the mouse was allowed to explore the objects for $5 \mathrm{~min}$. After a $1 \mathrm{~h}$ interval, the mouse was run into the second trial, in which one of the now familiar objects was in the same location as in trial 1, and a new object replaced the other object. On the third trial, one familiar object and a new object were presented.

The texture discrimination test was done in the same way as the objectshape recognition with a minor modification. The objects placed in the home cages were a plastic cup $(3 \mathrm{~cm}$ diameter and $5 \mathrm{~cm}$ height $)$ with a cover made from several different materials and textures. The mice explored different textures with their whiskers under infrared lighting condition.

Open-field test. To measure exploratory behavior, an open-field test (Plexiglas arena: $28 \times 24 \times 15 \mathrm{~cm}$ ), was run for $5 \mathrm{~min}$ under $\operatorname{dim}$ red light. The measures included: the number of lines crossed that divided the floor into four equal-size sectors and the number of events that the mouse displayed a stretch-attend posture that represented riskassessment behavior using whiskers and the snout.

Social behavior test was conducted following the open-field test. The subject mouse remained in the arena and an unfamiliar B6 mouse was introduced. The following behaviors were recorded during a $10 \mathrm{~min}$ session: the duration of contacts that the mouse approached to the stimulus mouse from the front and back of the body and the ratio of flight response to the opponent's approaches from the front or the back of the body.

The Y-maze spontaneous alternation test was performed to measure working memory (Sarnyai et al., 2000; Suryavanshi et al., 2014). This test is based on the interest of mice in exploration of new environments and requires spatial memory to distinguish between an already visited environment versus a novel one. Many parts of the brain are involved in this memory processing, such as the hippocampus, the septum, and the prefrontal cortex. The mouse was introduced into the Y-shaped maze (each arm length: $30 \mathrm{~cm}$, lane width: $5 \mathrm{~cm}$, arm wall height: $15 \mathrm{~cm}$ ) and was allowed to freely explore the Y-maze with no cutoff time. When the mouse made 20 choices, the test was done. We measured the ratio of spontaneous alternations by calculating the number of choices the subject made at the branch point.

\section{Results}

\section{ThNR1KO mice}

Our previous studies focused on genetic knock-out of NMDAR function in the barrel cortex (Iwasato et al., 2000, Datwani et al., 2002, Lee et al., 2005a). To evaluate the role of NMDAR activity at the presynaptic side of the thalamocortical circuitry and the postsynaptic side of the trigeminothalamic circuitry, we generated transgenic (Tg) mouse lines (5-HTTCre Tg) that express the Cre recombinase from the serotonin (5-HT) transporter (5-HTT) promoter (Fig. 1A). In the somatosensory system, 5-HTT is transiently expressed in thalamic nuclei from late embryonic to early postnatal stages but not expressed in neocortical layer 4 or brainstem nuclei throughout life (Lebrand et al., 1998, Narboux-Nême et al., 2008). We examined properties of Cre-mediated recombination of six lines of Tg mice by crossing them with Rosa-NLSLacZ (RNZ) (Kobayashi et al., 2013) and/or CAG-CAT-Z (Sakai and Miyazaki, 1997) reporter mice and identified two lines (Tg208 and Tg810), in which Cre-mediated recombination assessed by LacZ staining was highly restricted to the somatosensory, visual, and auditory thalamic nuclei (Fig. $1 B$ for Tg208; data not shown for Tg810). Cre-mediated recombination was also observed in the raphé nuclei and in deeper layers of medial neocortex such as the cingulate. Recombination in the SI cortex or in the brainstem trigeminal nuclei was negligible even in adulthood (Fig. 1B). These Cre-mediated recombination patterns were in 
A

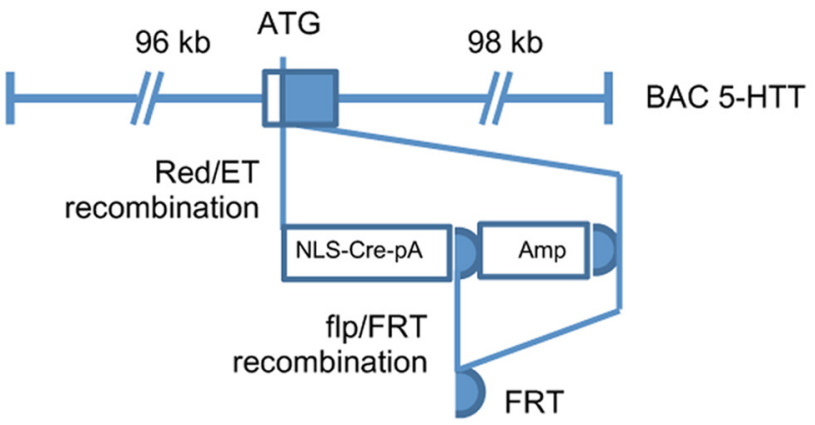

Adult
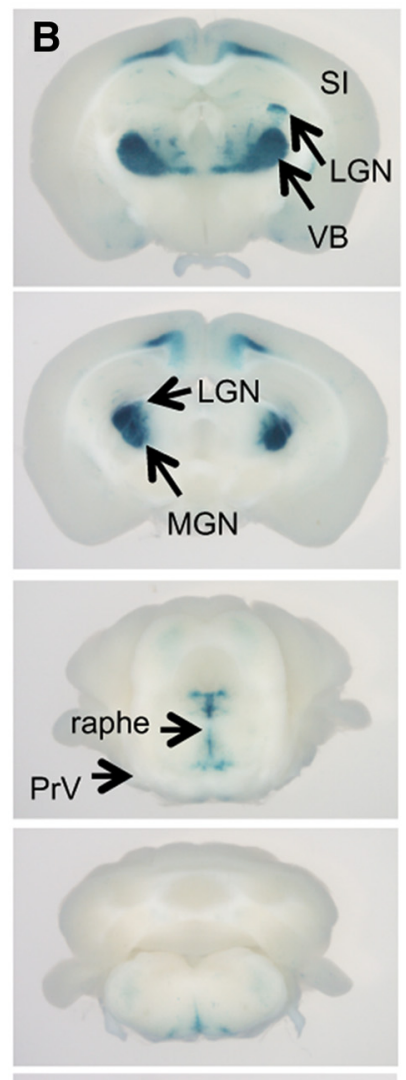

$\mathrm{Spl} \geqslant$

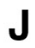

K

L
E15

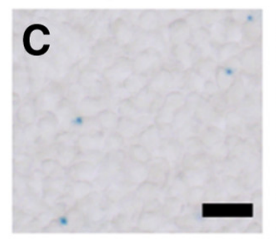

P0

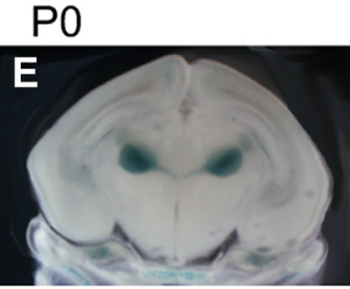

P7

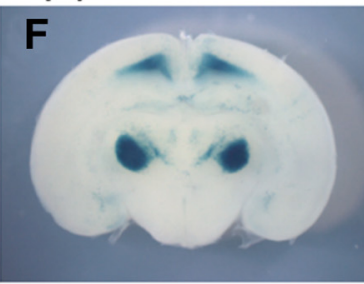

P7
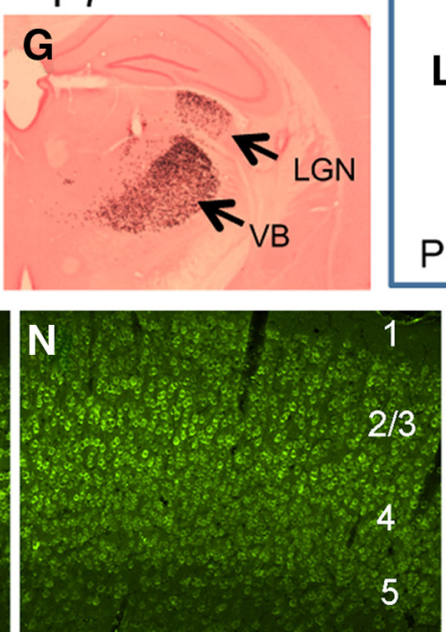
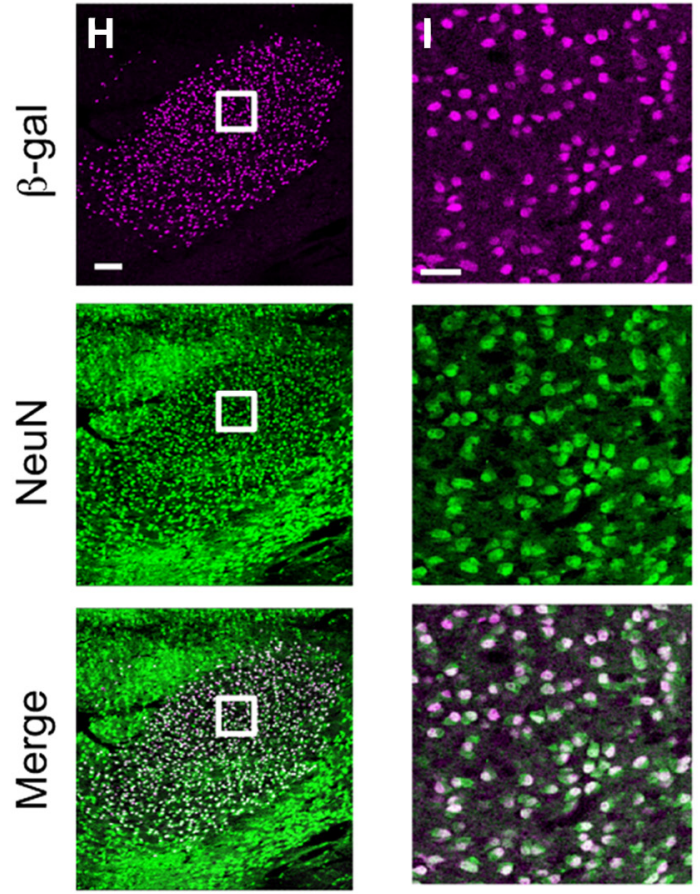

ThNR1KO
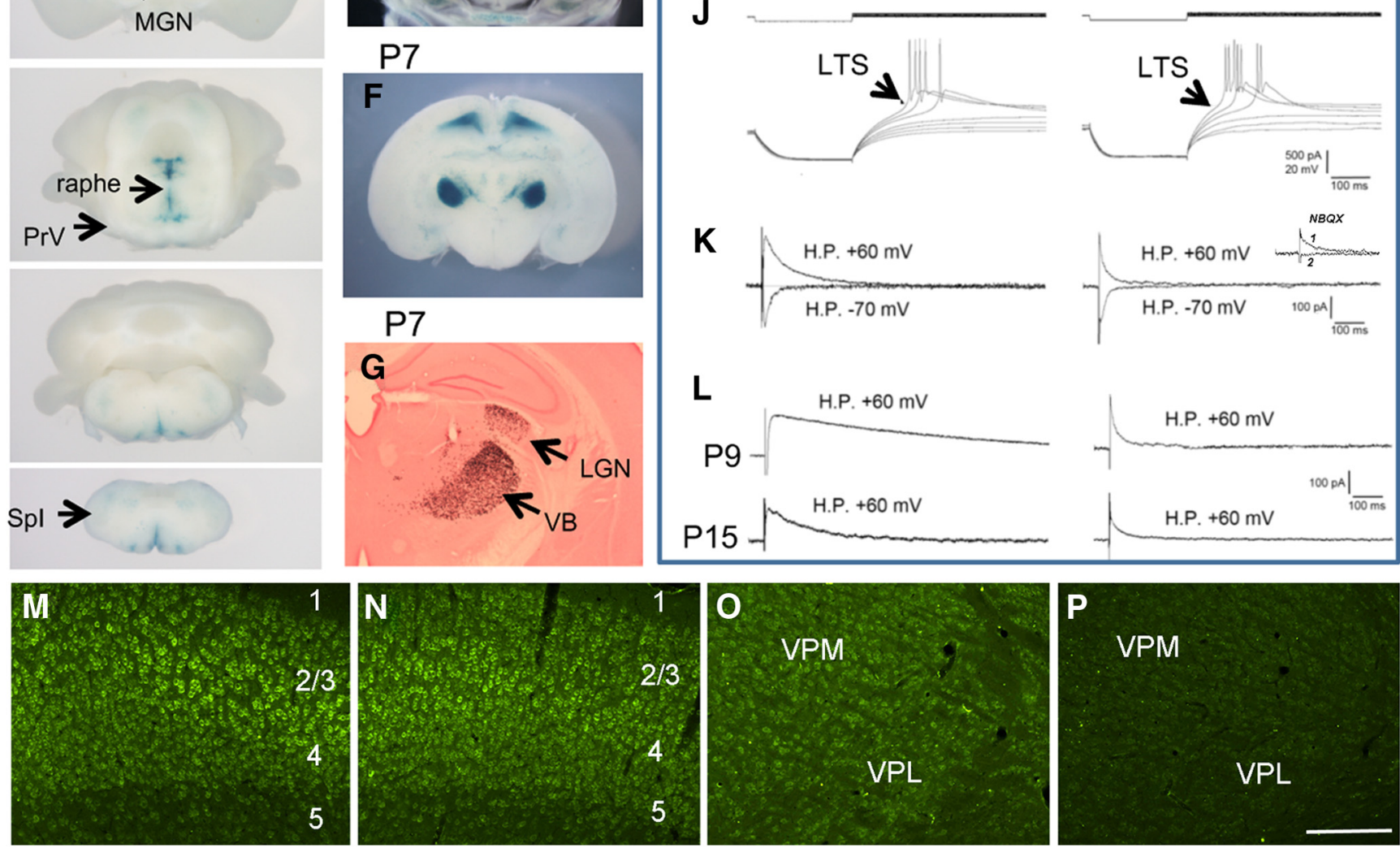

Figure 1. Generation of 5-HTTCre Tg and ThNR1KO mice. $A$, The translational initiation site of the serotonin transporter (5-HTT) gene on a BAC clone was replaced with the coding sequence of NLS-Cre, and the Amp selection marker was subsequently removed by flp/FRT recombination in bacteria. This BAC construct was microinjected into fertilized eggs to generate 5-HTTCre Tg mice. $\boldsymbol{B}$, In 5-HTTCre Tg mice crossed with RNZ reporter mice, (re-mediated recombination was detected in the sensory thalamus such as VB (somatosensory), lateral geniculate nucleus (LGN; visual) and medial geniculate nucleus (MGN; auditory), raphé, and deep layers of medial parts of the neocortex, but was not detected in the SI cortex and the trigeminal brainstem such as the PrV and Spl. LacZ-stained images of a 1-mm-thick coronal slice of 5-HTTCre Tg208;RNZ mouse at P38. C, D, Cre-meditated recombination assessed by LacZ stain in VB was first detected at E15 (C) and was dense atE17 (D). Scale bars: $25 \mu \mathrm{m}$. 5-HTTCre;RNZ embryo 30- $\mu \mathrm{m}$-thick coronal slices. $\boldsymbol{E}, \boldsymbol{F}$, In early postnatal development, (re-mediated recombination in VB is very high. Coronal slices of 5-HTTCre;RNZ mice at P0 ( $\boldsymbol{E} ; 400-\mu \mathrm{m}$-thick slice with LacZ stain) and P7 (F; 1-mm-thick slice with LacZ stain). $\mathbf{G}$, A 20 - $\mu$ m-thick coronal section from a P7 mouse (LacZ/Neutral red stain). $\boldsymbol{H}, \boldsymbol{I}$, Double immunohistochemistry of VB of 5-HTTCre;RNZ mouse slice ( $30 \mu \mathrm{m}$ thick) at P5 with anti- $\beta$-galactosidase and anti-NeuN (a neuronal nuclear marker) antibodies. $I$, Higher magnification images of the boxed regions in $\boldsymbol{H}$. These images were used for quantification of (re-mediated recombination. Scale bars: $\boldsymbol{H}, 100 \mu \mathrm{m} ; \boldsymbol{I}, 25 \mu \mathrm{m}$. $\boldsymbol{J}$ - $\boldsymbol{L}$, Comparison of (Figure legend continues.) 
most part similar between $\operatorname{Tg} 208$ and $\operatorname{Tg} 810(n>90$ in total) and similar to those previously reported for 5-HTTCre knock-in mice, in which an allele of endogenous 5-HTT gene is inserted and disrupted by the Cre recombinase gene (Zhuang et al., 2005; Narboux-Nême et al., 2008). In the knock-in mice, not all but notable numbers of layer 6 (and 5) neurons in the SI cortex display recombination. This contrasts to our $\operatorname{Tg} 208$ and $\operatorname{Tg} 810$ lines, which had very few SI layer 5 and 6 cortical neurons with recombination. In addition, unlike our 5-HTTCre Tg lines, the 5-HTTCre knock-in line has a disruption in an allele of the endogenous 5-HTT gene. This is particularly important when these Cre mice are used for barrel analyses: homozygous knock-out mice of 5-HTT have severely disrupted barrel patterns most likely due to the excess levels of 5-HT in the cortex; even heterozygous knock-out mice show mild barrel impairment (Persico et al., 2001). In the present study, we mainly used Tg208; in some histological analyses we used both $\operatorname{Tg} 208$ and $\operatorname{Tg} 810$ and always obtained consistent results. In our Tg mice, Cre-recombination in the thalamus was detected as early as E15 and increased quickly (Fig. 1C,D); in early postnatal period such as at $\mathrm{P} 0$ and $\mathrm{P} 7$, recombination in the VB was conspicuously high (Fig. $1 E-G$ ). Quantitative analyses at P5 demonstrated that $97.45 \pm 0.63 \%(n=8$ slices, two mice) of neurons (NeuN-positive cells) of VB thalamus had Cre-mediated recombination (LacZ positive; Fig. $1 H, I)$. We crossed these 5-HTTCre Tg mice with NR1 flox mice (Tsien et al., 1996) and obtained thalamus-specific NR1 KO $\left(\right.$ ThNR1KO $=5$-HTTCre;NR1 $\left.{ }^{\text {flox } /-}\right)$ mice.

We confirmed the loss of NMDAR function in the VB by performing electrophysiological recordings in oblique horizontal diencephalon slices (Castro-Alamancos, 2002; Kivrak and Erzurumlu, 2013). We found shortened postsynaptic excitatory responses in ThNR1KO VB neurons (Fig. 1J-L). In both control and ThNR1KO mice, LTSs mediated by T-type calcium channels were present after sudden release from hyperpolarization (Fig. $1 J)$. In control mice, stimulation of the trigeminal Lem induced an EPSC that had a longer duration at a holding potential of +60 $\mathrm{mV}$ and a short duration at $-70 \mathrm{mV}($ Fig. $1 \mathrm{~K})$, indicating that the EPSC is mediated by both AMPARs and NMDARs. That was the case for all $15 \mathrm{VB}$ neurons (from 10 mice) from which we made recordings. In ThNR1KO mice, Lem stimulation-induced EPSCs had similar short durations at different holding potentials (Fig. $1 \mathrm{~K}$ ) in all of the $8 \mathrm{VB}$ neurons (from five different $\mathrm{KO}$ mice) from which we made recordings. As shown in the inset of Figure $1 K$, the EPSC at $+60 \mathrm{mV}$ was completely blocked by NBQX (trace 1 before vs trace 2 after NBQX), indicating that VB neurons lacked NMDAR-mediated postsynaptic response. We also applied APV and found no change in the EPSC at $+60 \mathrm{mV}$ in $\mathrm{KO} \mathrm{VB}$ (data not shown). Another fact that supported the absence of NMDARmediated response in VB neurons of ThNR1KO mice is shown in

$\leftarrow$

(Figure legend continued.) electrophysiological properties of VB neurons between ThNR1KO and control mice. J, VB cells show similar low-threshold $\mathrm{Ca}^{2+}$ spikes. $\boldsymbol{K}$, Different duration in EPSCs at $+60 \mathrm{mV}$. The inset shows that the EPSC at $+60 \mathrm{mV}$ of KO VB is completely blocked by NBQX (trace 1 before vs trace 2 after NBQX), indicating absence of NMDAR-mediated response. $L$, Differences in developmental changes in decay of EPSCS at $+60 \mathrm{mV}$. All of these confirm that VB cells in ThNR1K0 mice lack NMDAR-mediated postsynaptic responses. $M, N$, NR1 expression in the barrel cortex of a control $(\boldsymbol{M})$ and a ThNR1KO adult mice $(\boldsymbol{N})$. Note that there is no apparent difference in cytoplasmic staining of cortical neurons between the control and knock-out cases. Cortical layers are indicated. $\mathbf{O}, \boldsymbol{P}$, In control mice neuron in the VPM and VPL components of the VB also stain positive for NR1 $(\boldsymbol{O})$, but staining is absent in the ThNR1KO VPM and VPL $(\boldsymbol{P})$, even though some distinct, unbound fluorescent secondary antibody particles can be seen. Scale bar, $M-P, 100 \mu \mathrm{m}$.
Figure $1 L$. The EPSC at $+60 \mathrm{mV}$ showed a developmental shortening in decay in control mice, suggesting a switch of NMDAR subunit NR2B to NR2A. However, the decay of EPSC at $+60 \mathrm{mV}$ of ThNR1KO mice remained the same. Finally, immunohistochemical staining with NMDAR1 antibody confirmed the lack of NR1 expression in the KO VB while immunostaining in the barrel cortex was robust (Fig. $1 M-P$ ).

The postsynaptic excitatory responses of $\mathrm{VB}$ neurons to trigeminal lemniscal inputs in the ThNR1KO mice were much shorter in duration than those of control mice, similar to what we reported for the barrel neuron responses to thalamocortical inputs in CxNR1KO mice (Lo et al., 2013).

\section{Differential patterning of the trigeminothalamic pathway in ThNR1KO mice}

Whisker-specific inputs are carried to the brain by the infraorbital (IO) branch of the maxillary trigeminal nerve. IO axons bifurcate upon entry into the brainstem and terminate within the $\mathrm{PrV}$ and the spinal trigeminal nucleus, where they form discrete terminal arbors [in subnuclei interpolaris (SpI) and caudalis]. These patterns were all absent in the global NMDAR mutant mice (Li et al., 1994; Kutsuwada et al., 1996) and partially present in the SpI. They were absent in the $\operatorname{PrV}$ of a transgenic line that we developed with lowered NMDAR levels in the PrV (Iwasato et al., 1997).

In ThNR1KO mice, both PrV and SpI barrelette patterns appeared indistinguishable from controls (Fig. $2 A-D$ ). In contrast, VB lacked barreloid patterning, and the nucleus appeared to be smaller in size (Fig. $2 E-H$ ). A similar reduction in the VPM portion of the VB following Tg NMDAR function reduction in the PrV has been reported previously (Lee and Erzurumlu, 2005). We used several markers for barreloid patterning in the VB and they all showed absence of barreloids at various developmental ages (Fig. 2). These results suggest that in the absence of functional NMDARs in the sensory thalamus, trigeminal and dorsal column lemniscal axons fail to form whisker- and paw-related patterns in their respective target zones, the ventroposteromedial (VPM) and ventroposterolateral (VPL) components of the VB complex. This was especially evident from VGLUT2 immunostaining of the thalamus sections (Fig. $2 K, L$ ). Immunostaining of 5-HTTpositive axons also showed absence of patterning in the mutant VB (Fig. 2I,J). Subsequently, there was no patterned CO staining (reflective of presynaptic and postsynaptic activity) or barreloid (cellular) patterning (Fig. $2 \mathrm{E}-\mathrm{H}$ ).

\section{Disruption of NMDARs in the thalamus affects barrel formation in the SI cortex}

Next, we examined the development of TCA terminal and cellular (barrel) patterning in layer 4 of the SI cortex. We used generic markers for TCAs, 5-HTT, and VGLUT2 immunohistochemistry. In coronal brain sections the laminar distribution of TCAs in ThNR1KO mice was similar to controls (Fig. 3). However, their density appeared low and they did not form notable segmentation.

TCA patterning defects could be seen easily in sections through the flattened cortices. We took advantage of our recently developed TCA-GFP Tg mice, which express membrane boundenhanced GFP in 5-HTT producing cells such as VB neurons (Mizuno et al., 2014). Crossing the ThNR1KO mice with TCAGFP mice allowed us to visualize TCA patterning in the barrel cortex (Fig. 4D). CO staining (a standard histochemical stain that allows visualization of presynaptic and postsynaptic patterning in the whisker-barrel neuraxis) revealed the absence of barrel pat- 

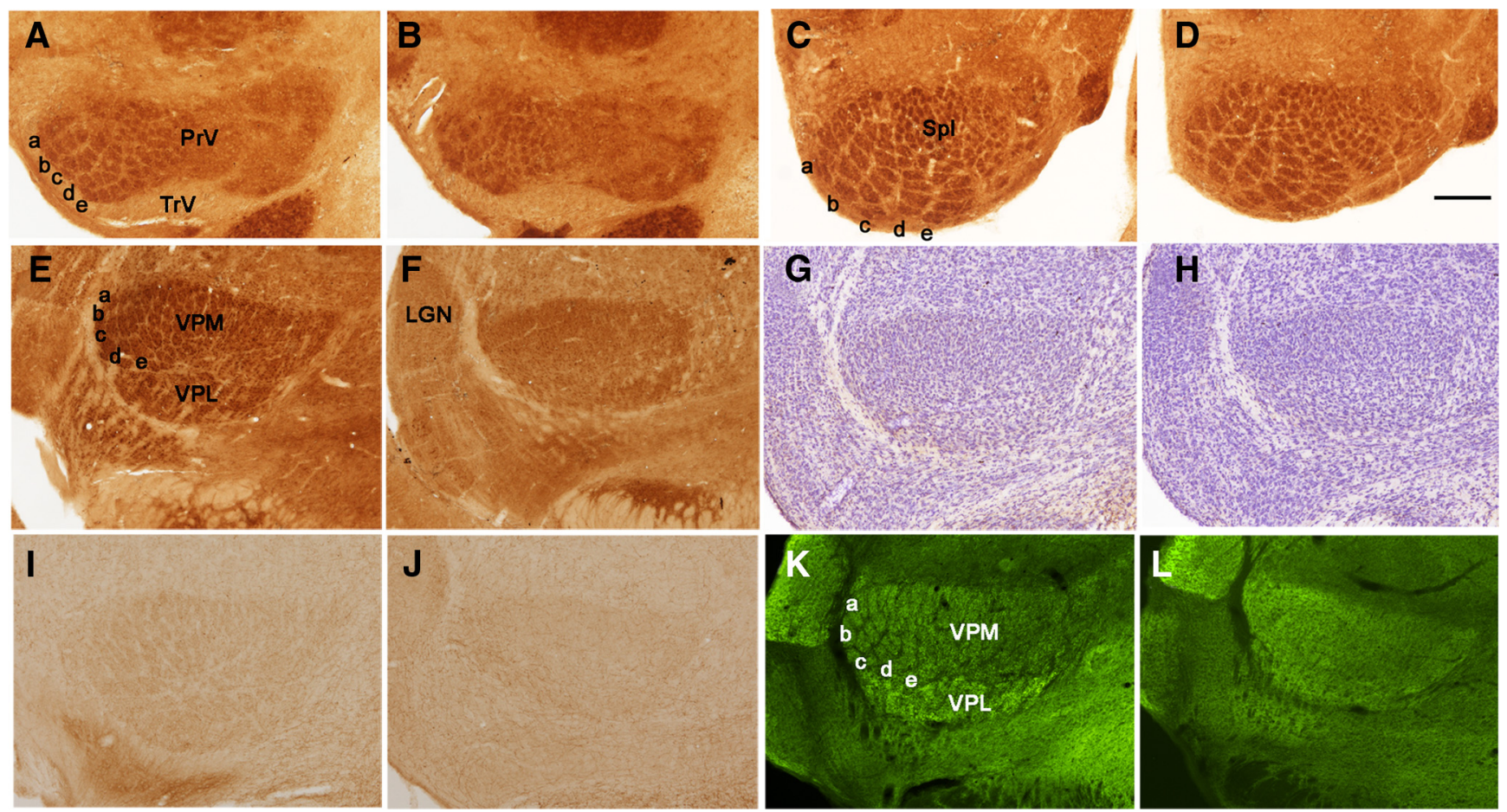

Figure 2. Whisker-specific patterning in subcortical trigeminal centers. $\boldsymbol{A}-\boldsymbol{D}$, Barrelette patterns in the $\operatorname{PrV}(\boldsymbol{A}, \boldsymbol{B})$ and $\operatorname{Spl}(\boldsymbol{C}, \boldsymbol{D})$ of the spinal trigeminal nucleus in ThNR1K0 mice at $\operatorname{P5}(\boldsymbol{B}, \boldsymbol{D})$ appear very similar to those of P5 controls $(A, C$. C $C$ staining, barrelette rows a- $e$ are indicated. Unlike the trigeminal brainstem, barreloids are absent in the VPM and VPL components of the VB in ThNR1K0 mice $(\boldsymbol{F}, \boldsymbol{H}, \boldsymbol{J}, \boldsymbol{L})$. Photomicrographs in $\boldsymbol{E}-\boldsymbol{H}$ compare the VB of ThNR1K0 and control mice at P5, at P7 $(\boldsymbol{I}, \boldsymbol{J})$, and at $P 9(\boldsymbol{K}, \boldsymbol{L})$ with $C \mathbf{0}$ staining $(\boldsymbol{E}, \boldsymbol{F})$, Nissl staining $(\boldsymbol{G}, \boldsymbol{H}), 5-H T T(\boldsymbol{I}, \boldsymbol{J})$, and VGLUT2 immunohistochemistry $(\boldsymbol{K}, \boldsymbol{L})$. Scale bar, $200 \mu \mathrm{m}$. LGN, Lateral geniculate nucleus; TrV, trigeminal tract.

terns (Fig. 4F). Pattern deficits could be seen with various other cellular and nuclear markers (NeuN, DAPI, Cux1, and Nissl stain; Fig. $4 B, G, H, I)$ and the TCA markers (5-HTT, VGLUT2 immuno, and GFP expression; Fig. $4 A, D, E)$. They all showed that TCAs targeted the proper area and laminae of the SI cortex but had a rather diffuse and blurred patterning corresponding to the caudal large whiskers of the snout, while those normally representing anterior whiskers and sinus hairs were absent (Fig. 4). Density of GFP-positive axons was also low, yielding a much darker image compared with controls under the same epifluorescence conditions (Fig. $4 D, D^{\prime}$ ).

\section{Reduced transmitter release probability of thalamocortical afferent terminals in ThNR1KO barrel cortex}

We recorded from layer 4 excitatory neurons of the barrel cortex to study thalamocortical synaptic transmission. In both control and ThNR1KO mice, layer 4 excitatory neurons showed adapting, regular spiking during membrane depolarization (Fig. $5 A, B)$. Stimulation of the VB induced EPSCs with a long duration at $+60 \mathrm{mV}$ holding potential and with a short duration at $-70 \mathrm{mV}$ in both phenotypes (Fig. $5 C, D$ ). Thus, postsynaptic NMDARs of the thalamocortical circuitry are not impaired and layer 4 excitatory cells have both AMPARs and NMDARs.

Previous studies on mutant mice with impaired glutamatergic neurotransmission at thalamocortical synapses, either by way of failure in presynaptic vesicle fusion or VGLUTs, also showed significant defects in barrel cortex patterning and function (Narboux-Nême et al., 2012; Li et al., 2013). To investigate the presynaptic input strength in ThNR1KO mice, we used a pairedpulse protocol to test the transmitter release probability (Pr) of TCAs. In control mice, the amplitude of the second EPSC was smaller than that of the first EPSC (paired-pulse depression; Fig. $5 E$ ), indicating that the TCAs have a high $\mathrm{Pr}$, because the first pulse depletes the available transmitter and the second pulse causes less transmitter release. And as a consequence, the PPR was low. The averaged PPR was $50.4 \pm 3.7 \%(n=15$; Fig. $5 G$, white bar). In sharp contrast to this, in ThNR1KO mice, the second EPSC was always larger than the first EPSC (paired-pulse facilitation; Fig. $5 F$ ) indicating a very low TCA Pr; the first VB stimulation causes a small postsynaptic response, and the buildup of $\mathrm{Ca}^{2+}$ in the presynaptic terminal leads to an increased release probability on the second response and a higher PPR. The averaged PPR was $136.8 \pm 6.7 \%(n=9$; Fig. $5 G$, black bar $)$. The difference in PPR between Control and ThNR1KO mice was highly significant $(p<0.0001)$. The low Pr of thalamocortical terminals of ThNR1KO mice means that the terminals release much less synaptic transmitter during each thalamocortical nerve impulse.

\section{How does the "barreloidless," NMDAR-impaired thalamus relay whisker inputs to the neocortex?}

We performed optical imaging with voltage-sensitive dye $\mathrm{RH}$ 1691 to investigate the activation patterns in the SI cortex following stimulation of the contralateral C2 or E2 whisker. In control animals $(n=6)$, voltage-sensitive dye signal appeared just after the frame when the stimulus was presented and reached its peak 30-40 ms after the stimulus onset, and then decreased and returned to baseline within 50-60 ms (Fig. 6A). Optical signals were located in a discrete spot corresponding to the E2 barrel region, as has been reported in similar imaging studies (Ferezou et al., 2006; Lo et al., 2013). In ThNR1KO mice $(n=6)$, optical signals were much weaker when the signal was calculated as fluorescence from the area imaged (Fig. 6B). Aside from being weak, optical signals were also less focalized in the knock-out animals compared with control animals (Fig. 6A,B). We could also see that the numbers of pixels with fluorescence value $>90 \%$ of all 

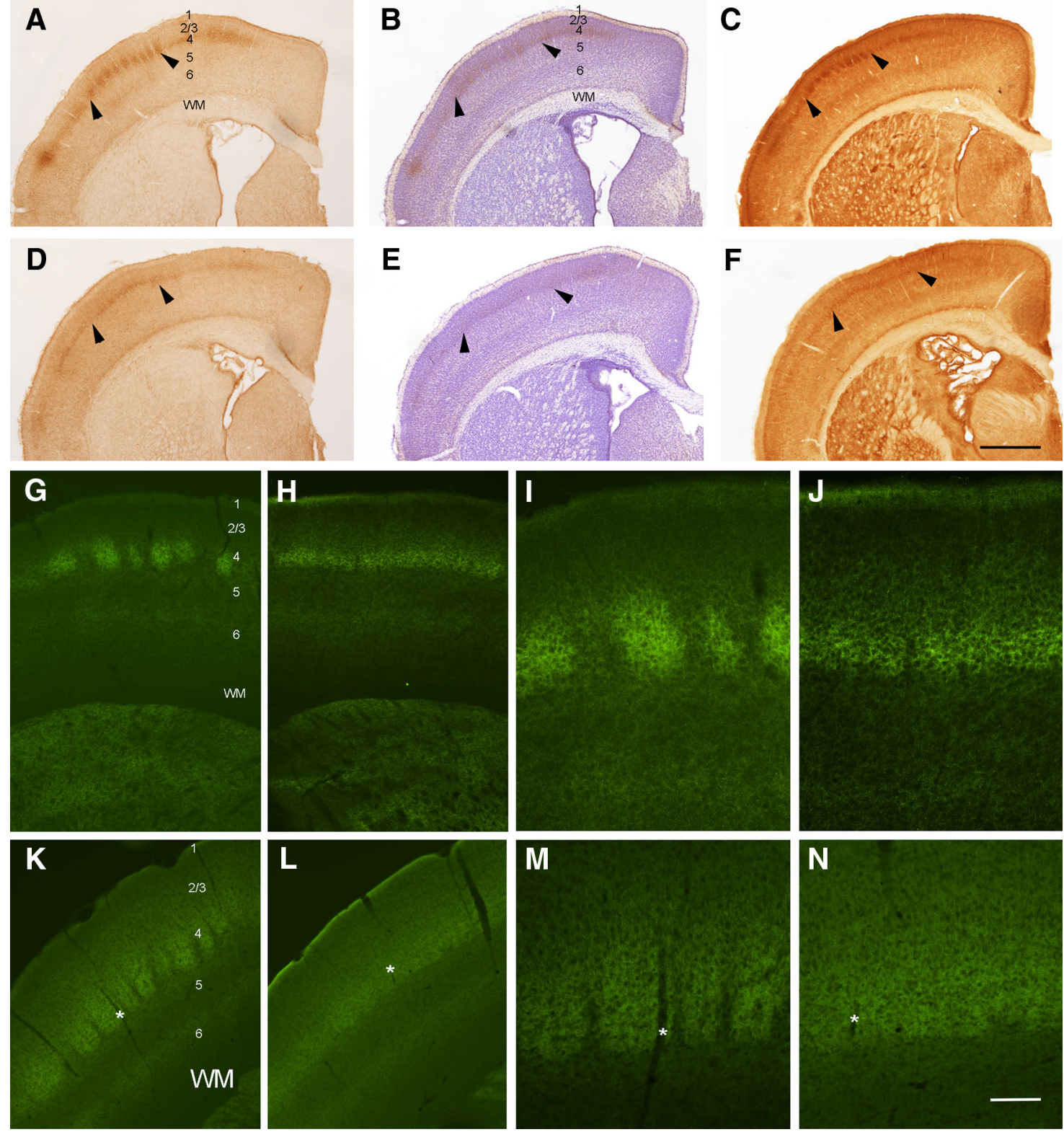

Figure 3. Cortical lamination and thalamocortical axon targeting. Immunolabeling for $5-H T T(A, D)$, Nissl staining $(\boldsymbol{B}, \boldsymbol{E})$, and $C 0$ histochemistry $(\boldsymbol{C}, \boldsymbol{F})$ in coronal sections indicate that TCAs in ThNR1K0 mice target primarily layer $4(\boldsymbol{D}-\boldsymbol{F})$ but, unlike the controls $(\boldsymbol{A}-\boldsymbol{C})$, they do not form discrete terminal patches and cellular barrels are absent. G-J, Show VGLUT2 immunostaining at P7 in control $(\boldsymbol{G}, \boldsymbol{I})$ and ThNR1KO mice $(\boldsymbol{H}, \boldsymbol{J})$ at low $(\boldsymbol{G}, \boldsymbol{H})$ and high $(\boldsymbol{I}, \boldsymbol{J})$ power. Note that the apparent density of TCAs in the knock-out case is weaker. $\boldsymbol{K}-\boldsymbol{N}$, Illustrate VGLUT2 immunostaining in adult control $(\boldsymbol{K}, \boldsymbol{M})$ and ThNR1K0 mice $(\boldsymbol{L}, \boldsymbol{N})$. $\boldsymbol{L}$ and $\boldsymbol{N}$ are higher power views of layer 4 and asterisks mark the same blood vessels in low- and high-power micrographs. Cortical layers are marked in some photomicrographs. WM, white matter. Arrowheads point to layer 4 barrel fields. Scale bars: (in $F$ ) $A-F, 400 \mu \mathrm{m}$; (in $N) I, J, M, N, 50 \mu \mathrm{m} ; G, H, K, L, 150 \mu \mathrm{m}$.

the pixels in the imaging area were much lower (Fig. $6 C, D)$. Additionally, the $\mathrm{C} 2$ whisker-evoked signal in the mutant barrel field was roughly topographic but diffuse with an irregular shape and less clear border (Fig. 6C,D). These results indicate weakened and less specific whisker-evoked activity in the barrel cortex.

\section{Behavioral phenotype of the ThNR1KO mice}

The behavioral tests (Figs. 7, 8), we used can be classified into four categories: (1) general whisker sensation and paw sensation: in this group we have the gap-crossing, edge-approach, sticky paper, and grid-walking tests; the last two tests are for the paw representation, which is normally patterned (but absent in the knock-out mice) in the VPL portion of the VB complex; (2) general sensorimotor ability tests: bridge crossing, swimming, and hanging from a wire; (3) whisker-specific sensory tests: ex- ploratory and discriminative whisking, and object-shape and texture-discrimination tasks; and (4) cognitive and social behavior tests: open field, spatial memory (Y-maze), and social behavior. The tests we chose were not a generic battery of mouse behavior tests. Normally raised B6 mice show poor performance in many of these tests when their whiskers are bilaterally clipped (H. Arakawa and R.S. Erzurumlu, submitted).

In whisker and paw sensation tests, performance of ThNR1KO mice was significantly poor. In the gap-crossing test, both under light and dark conditions, they crossed much shorter differences (Fig. 7). Whisker- and paw sensory-dependent floating in water score was low. In the edge-approach test the distance for body reaching was also shorter than controls. A striking difference was observed between the mutant and control groups in the sticky paper test. While the control animals quickly removed 

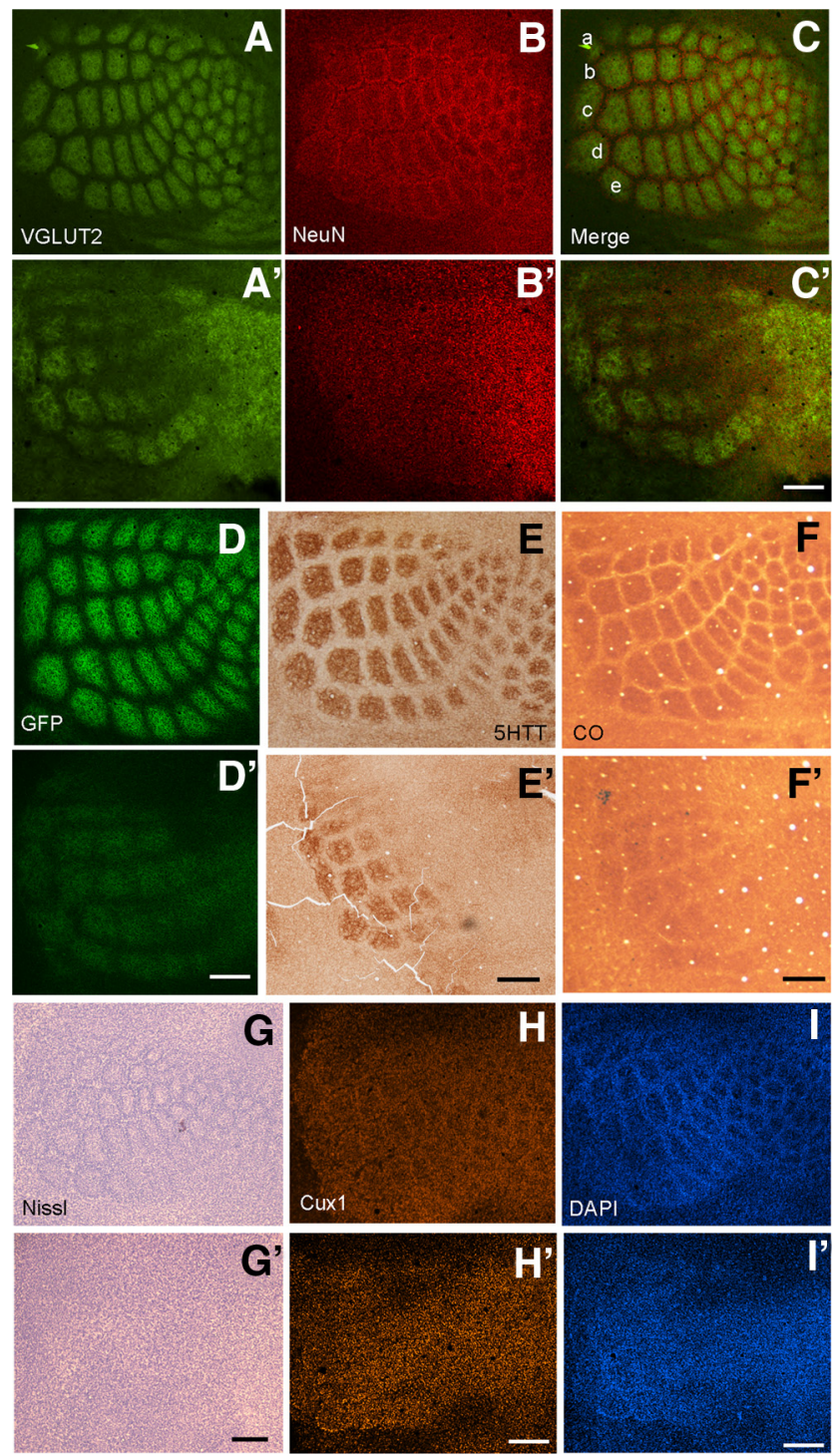

Figure 4. Altered barrel fields in ThNR1KO mice. A variety of cellular, axonal, and mitochondrial markers all showed that barrels fail to develop in ThNR1KO mice even though an incomplete and ill-defined TCA terminal patterning related to large, caudal whiskers developed. $\boldsymbol{A}, \boldsymbol{B}$, Barrel patterning as seen with VGLUT2 $(\boldsymbol{A})$ and $\operatorname{NeuN}(\boldsymbol{B})$ of control mice. $\boldsymbol{A}^{\prime}, \boldsymbol{B}^{\prime}$, Show similar cortical views from ThNR1K0 mice. $\boldsymbol{C}, \boldsymbol{C}^{\prime}$, Respective merged images; whisker barrel rows a-e are indicated. $\boldsymbol{D}, \boldsymbol{D}^{\prime}$, Compare TCA terminal patterning in control (TCA-GFP) and ThNR1K0;TCAGFP mice at P7, respectively, visualized by GFP fluorescence. Note that with similar imaging conditions the GFP labeling is weak in the mutant (ThNR1K0;TCA-GFP) mouse cortex. Similar pairs of micrographs are shown for 5-HTT immunostaining $\left(\boldsymbol{E}, \boldsymbol{E}^{\prime}\right), \mathrm{CO}$ staining $\left(\boldsymbol{F}, \boldsymbol{F}^{\prime}\right)$, Nissl staining $\left(\boldsymbol{G}, \boldsymbol{G}^{\prime}\right)$, Cux1 immunostaining $\left(\boldsymbol{H}, \boldsymbol{H}^{\prime}\right)$, and DAPI staining $\left(\boldsymbol{I}, \boldsymbol{I}^{\prime}\right)$. Scale bars, $250 \mu \mathrm{m}$.

the paper from their paw, mutant mice took much more time. Significant differences were also observed in the grid-walking test (Fig. 7).

In general sensorimotor tests, ThNR1KO mice took a longer time to cross the bridge to a safe platform compared with control mice, but their motor ability to hang from a wire was not impaired (Fig. 7).

Previous reports identified two classes of "whisking” behavior in mice and rats: a large amplitude "exploratory" whisking at $\sim 6-10 \mathrm{~Hz}$ and a lower amplitude high-frequency $(>10 \mathrm{~Hz})$ "discriminative" whisking pattern (Carvell and Simons, 1990, 1995; Landers and Philip Zeigler, 2006). Exploratory whisking is common while mice move around; discriminative whisking is char-
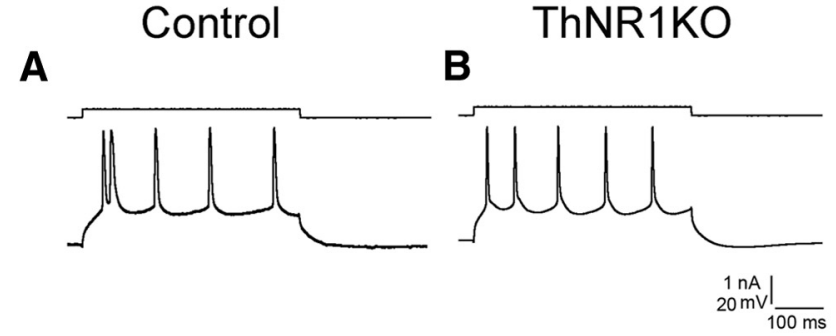

C

D
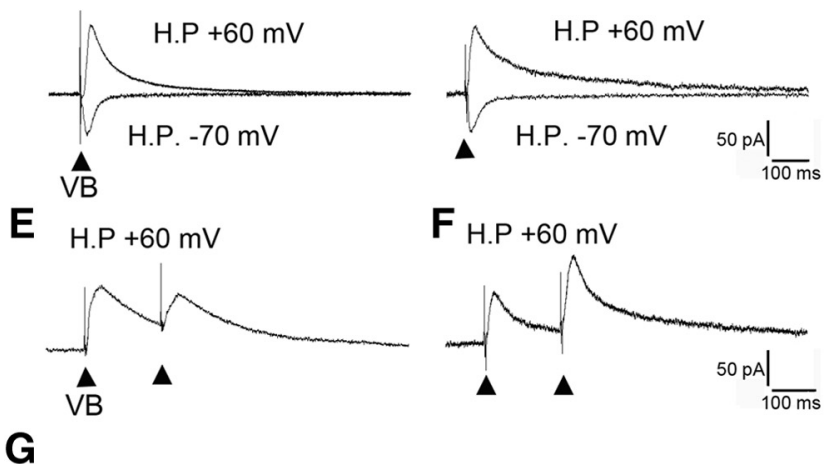

$\mathbf{G}$

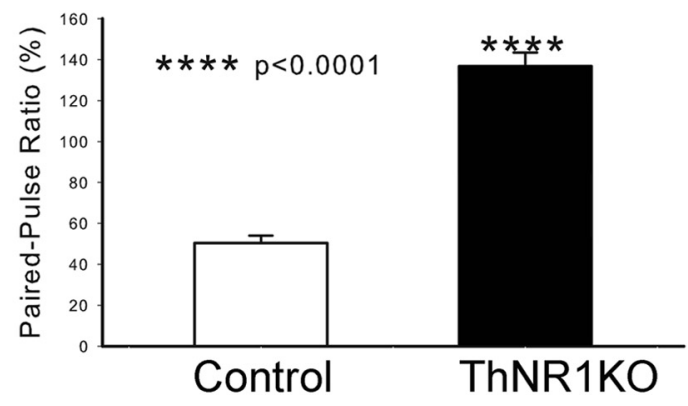

Figure 5. PPR in control and ThNR1KO mice. $\boldsymbol{A}, \boldsymbol{B}$, In both control and ThNR1KO mice, layer 4 cells showed adapting regular spiking during membrane depolarization. $C, D$, Stimulation of VB induced EPSCs with a long duration at $+60 \mathrm{mV}$ holding potential (H.P.) and with a short duration at $-70 \mathrm{mV}$ not only in control, but also in ThNR1KO mice, indicating that layer 4 cells have both AMPARs and NMDARs. $\boldsymbol{E}$, In control mice, the amplitude of the second EPSC was smaller than that of the first EPSC (paired-pulse depression), indicating that the TCAs have a high transmitter release probability. Arrowheads indicate VB stimulation. The averaged PPR was $50.4 \pm 3.7 \%(n=15 ; \boldsymbol{G}$, white bar). $\boldsymbol{F}$, In ThNR1KO mice, the second EPSC was always larger than the first EPSC (paired-pulse facilitation), indicating that the transmitter release probability of thalamocortical terminals was low. The averaged PPR was $136.8 \pm 6.7 \%(n=9$, $\mathbf{G}$, black bar). $\mathbf{G}$, The difference in PPR between control and ThNR1KO mice was highly significant $(p<0.0001)$

acteristic when the whiskers come into contact with an object. These whisking patterns are distinct from whisker movements during breathing, which are typically slow vibrations at $\sim 5 \mathrm{~Hz}$. We observed whisking with a high-speed camera (120 fps) and measured the frequencies and types of whisking when mice whisked in the air or investigated an object (Fig. 8). We found that mice tended to show symmetrical whisking (horizontal movement in all directions) when they did not contact an object and active whisking (bundled and oriented movement with a high pitch forward) toward an object presented. ThNR1KO mice displayed a lower frequency in active whisking, but not in symmetry whisking, compared with controls $\left({ }^{\star} p<0.05\right)$. Control mice show faster frequency in active whisking than symmetry whisking ( ${ }^{\#} p<0.05$; Fig. 8 ). When mice were presented with an object, control mice showed active whisking in a high ratio compared withThNR1KO mice (Fig. 8). 

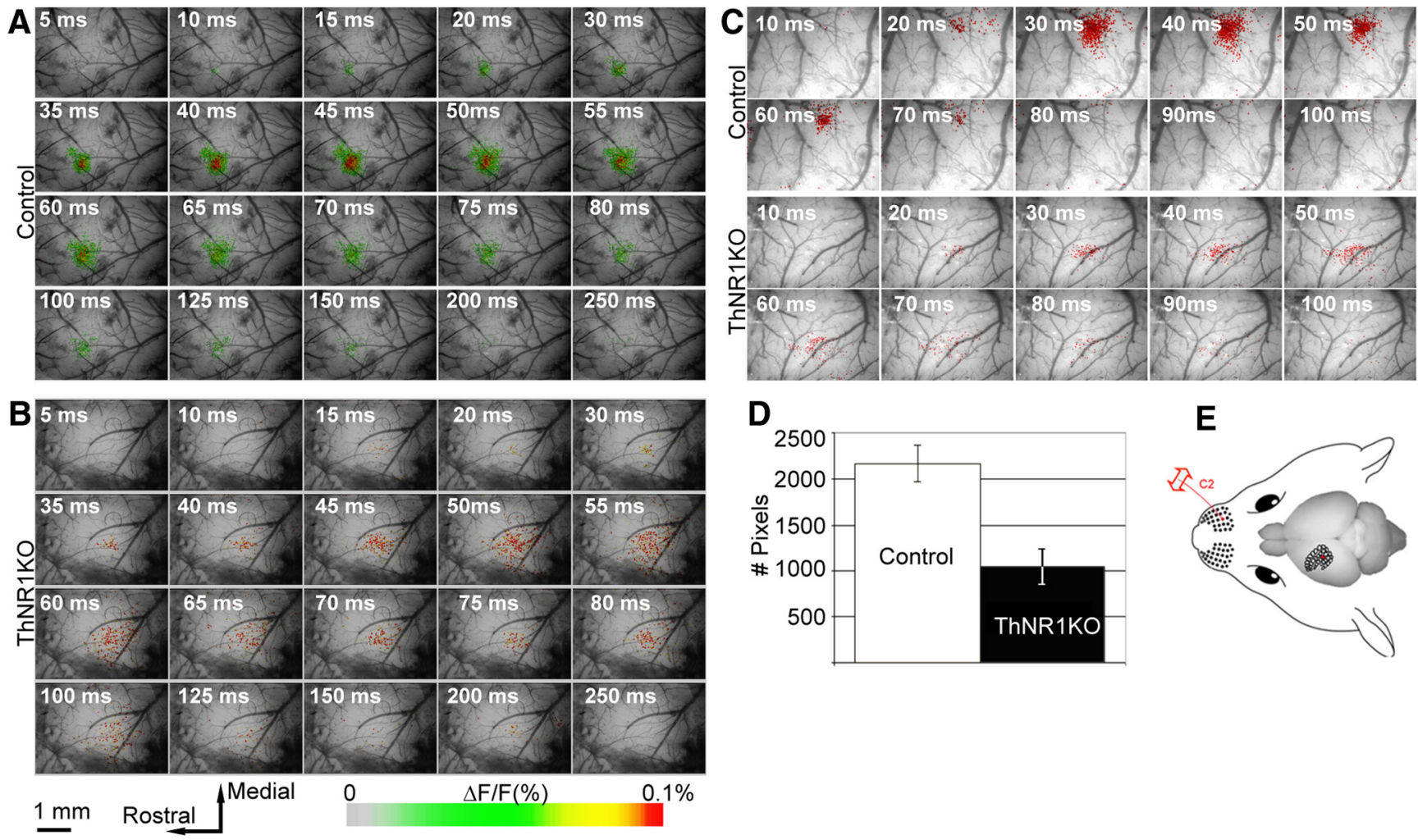

Figure 6. Comparison of voltage-sensitive dye optical imaging in control and ThNR1KO barrel cortex. A, Pseudocolor maps showing single-whisker (E2) stimulation fluorescence changes in a control mouse. The time after stimulus onset is indicated at the top left corner of each image; duration of each frame is $5 \mathrm{~ms}$. $\boldsymbol{B}$, Voltage-sensitive dye optical images showing single-whisker stimulation fluorescence changes in a ThNR1KO mouse. The time after stimulus onset is indicated at the top left corner of each image; duration of each frame is $5 \mathrm{~ms}$. Note that the activated area in the barrel cortex of the knock-out mouse has a much less distinct border and is less focalized compared with the control case. C, Examples of imaging data showing only the pixels (red dots) with the highest value ( $>90 \%$ of all pixels in the entire field of view) of fluorescence changes after ( 2 whisker stimulation in a control and a ThNR1KO mouse. The time after stimulus onset is indicated at the top left corner of each image; duration of each frame is $5 \mathrm{~ms}$. D, Quantitative analysis of the number of pixels with overthreshold value of signal ( $x$-axis) for the control and ThNR1K0 mice ( $y$-axis). Number of pixels with the highest value of fluorescence is calculated at $40 \mathrm{~ms}$ after the stimulus onset. $\boldsymbol{E}$, Illustration of the $(2$ whisker stimulation and the barrel field.

In discriminatory testing, there were notable differences between the ThNR1KO and control mice. In both the objectrecognition and object-texture discrimination tests, two identical objects were presented in the home cage on Trial 1 . On Trials 2 and 3, one of these objects was changed to a novel one. If mice recognize a novel object, they tend to investigate the novel object more than a familiar object presented on the previous trial (trial difference compared with Trial $\left.1 ;{ }^{*} p<0.05\right)$. Mice were able to see the objects visually presented in their cages in the objectshape recognition test, but they were able to use only tactile/ texture information about objects in the object-texture recognition test. Significant group differences (compared with controls, ${ }^{*} p<0.05$ ) were found on Trials 2 and 3 in the texture recognition test (Fig. 8top, right). Briefly, ThNR1KO mice showed a similar preference ratio on Trials 2 and 3 with Trial 1 , while control mice displayed a higher novel preference on Trials 2 and 3 compared with Trial 1 . These data suggest that control mice were able to distinguish objects' novelty by visual cue (shape) and tactile cue (texture), while ThNR1KO mice were able to distinguish objects' novelty by these shape differences but not by objects' texture differences.

In the last part of our behavioral analyses, we tested the mice for spatial memory, exploratory behavior, and social behaviors. In the open-field measurement, we observed exploration of mice in a dimly lit (red light) field, which allowed us to see whiskerdependent exploratory tendencies in mice. In the Y-maze spontaneous alternation (working memory) and open-field tests, we did not see differences between the mutant and control mice.
In the social behavior test, significant differences were present between the groups $\left({ }^{\star} p<0.05\right)$. Social contacts were counted as the duration that the mouse's head contacted the opponent's body (front or back of the opponent's bodies). Flight response indicated the ratio of the response in the total events of contacts from the opponent. ThNR1KO mice display a decreased contact to the front of the opponent and show remarkably increased flight response when the opponent contacts their back (Fig. 8). Due to recombination conditions in our mice, we cannot attribute these social and cognitive behavioral deficits solely to NMDAR loss of function in the sensory thalamus; the serotonergic system arising from the midbrain may also contribute.

\section{Discussion}

Previously, we and others showed that when excitatory cortical neurons lack functional NMDARs, they fail to detect patterning of presynaptic TCA inputs (Iwasato et al., 2000; Datwani et al., 2002; Lee et al., 2005a; Espinosa et al., 2009; Mizuno et al., 2014). Furthermore, earlier studies revealed that when NMDAR function is disrupted or reduced globally, brainstem barrelette patterning is impaired (Li et al., 1994; Kutsuwada et al., 1996), and all the patterns throughout the trigeminal system are lost (Iwasato et al., 1997). The requirement for coincidence detection property of NMDARs in patterning of whisker-barrel neuraxis was also demonstrated by a study in which a point mutation to the Grin 1 (NR1) gene led to the expression of functional NMDARs that are $\mathrm{Mg}^{2+}$ insensitive and $\mathrm{Ca}^{2+}$ impermeable (Rudhard et al., 2003). These mice lacked brainstem barrelettes, while the topographic 
<General whisker sensation>

Gap crossing test

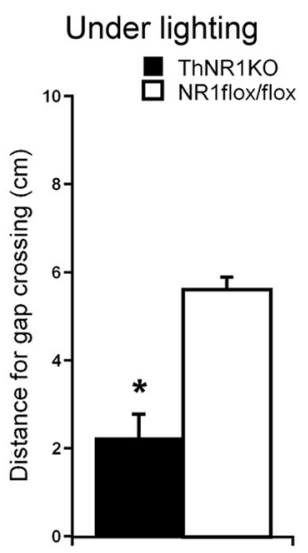

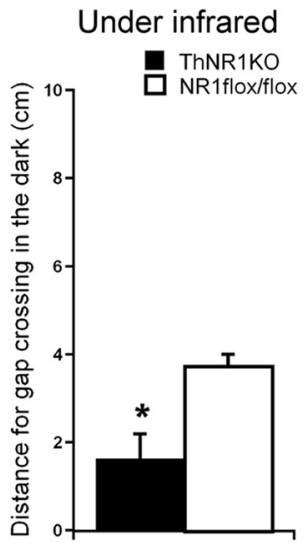
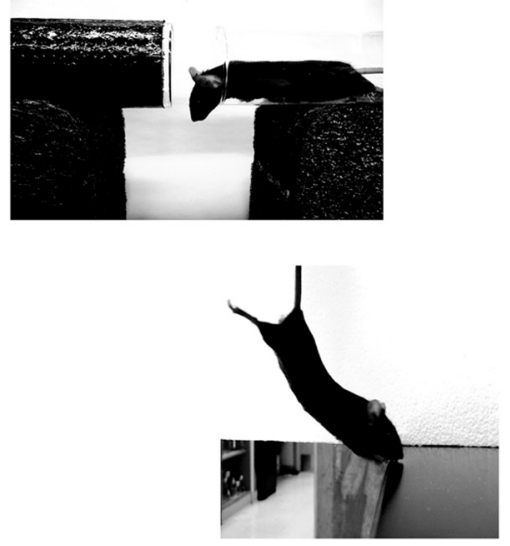

Edge approach test

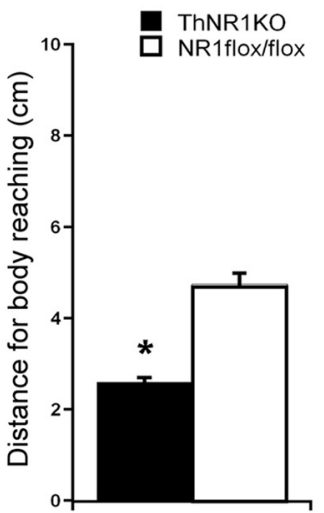

$<$ Paw sensation>

Sticky paper test
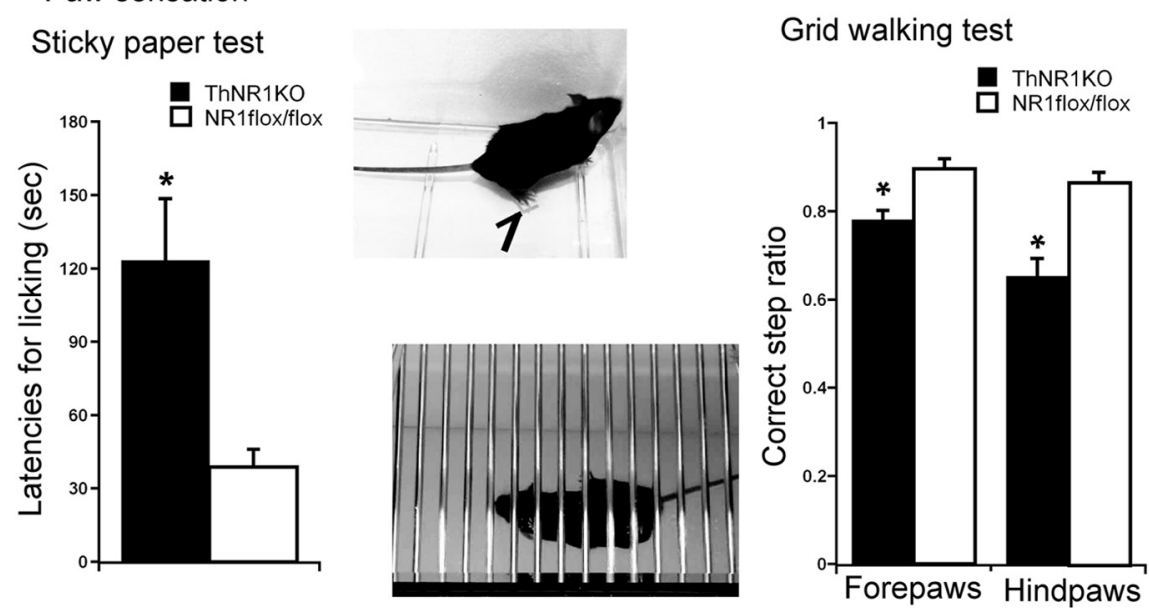

$<$ General sensorimotor ability $>$
Bridge walking test
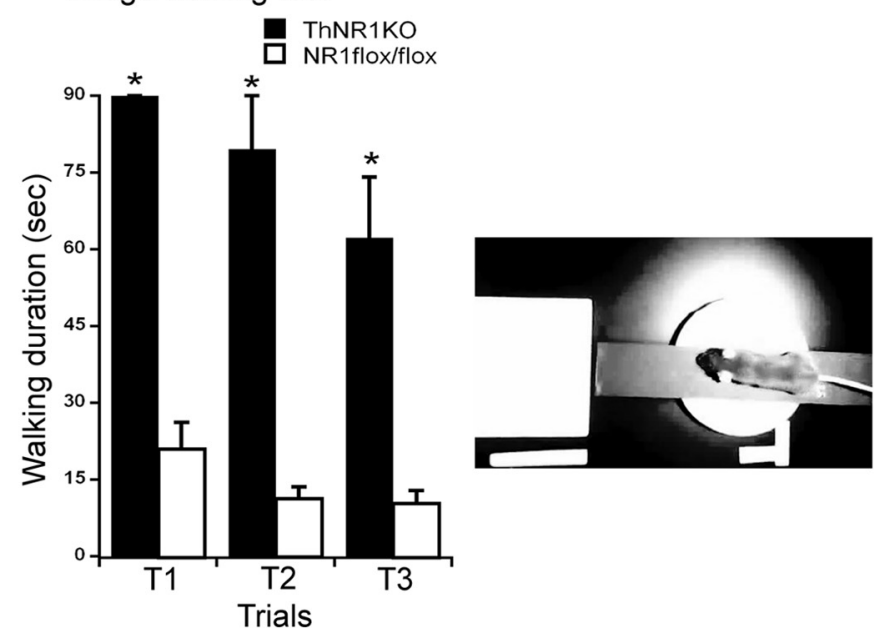

Wire hanging test

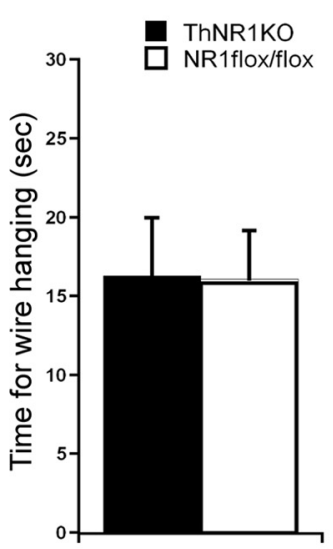

Swimming test
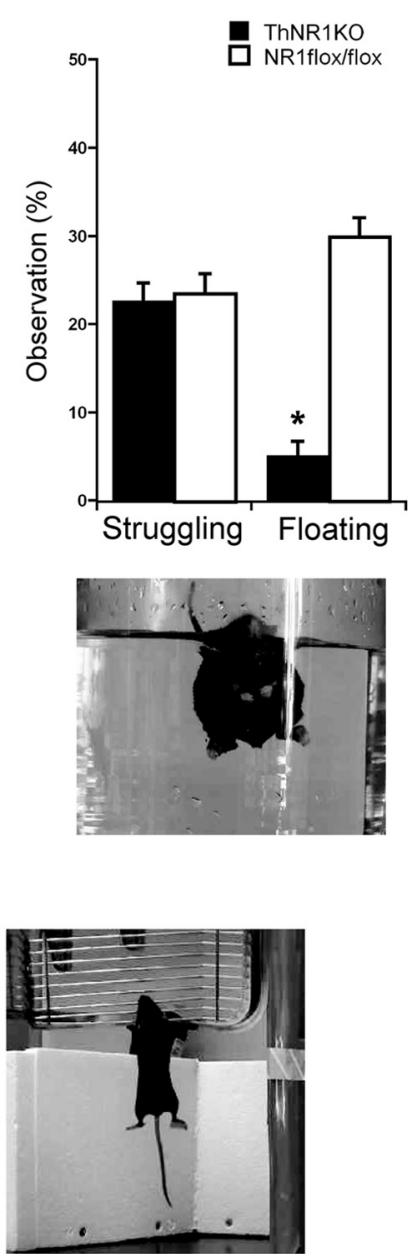

Figure 7. Whisker and paw sensation is impaired in ThNR1KO mice. In the gap-crossing test, ThNR1KO mice cross shorter gap distances than controls (NR1 flox/flox) both in the light $\left(t_{(14)}=\right.$ $5.73782, p<0.001)$ and in the dark (infrared) condition $\left(t_{(10)}=3.4295, p=0.0063\right)$. In the edge-approach test, ThNR1K0 mice reach a shorter distance compared with control mice $\left(t_{(14)}=\right.$ $8.6346, p<0.0001)$. In the swimming test, ThNR1K0 mice show a similar level of paddling $\left(t_{(14)}=0.2614, p=0.797\right)$, but significantly shorter floating time than controls $\left(t_{(14)}=8.8859, p<\right.$ $0.0001)$. ThNR1KO mice display a longer latency for licking a sticky paper off their hindpaw than controls $\left(t_{(8)}=3.231, p=0.012\right)$. In the grid-walking test, ThNR1KO mice show lower correct step ratio than controls for both the forepaws $\left(t_{(14)}=4.2037, p=0.0009\right)$ and the hindpaws $\left(t_{(14)}=4.62988, p=0.0004\right)$. In the bridge-walking test, ThNR1K0 mice show significantly longer duration for reaching a platform than controls (two-way ANOVA: strain $F_{(1,14)}=81.616, p<0.0001$; trial $F_{(2,28)}=5.141, p=0.0125$; and strain $\times$ trial $\left.F_{(2,28)}=1.373, p=0.2699\right)$. However, in the wire hanging test, there was no significant difference in hanging duration $\left(t_{(14)}=0.0435, p=0.9659\right)$ between the ThNR1KO and the control mice. 
Whisking
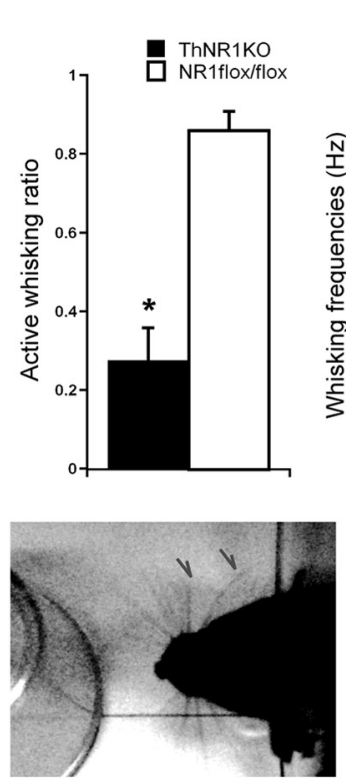

Symmetry whisking
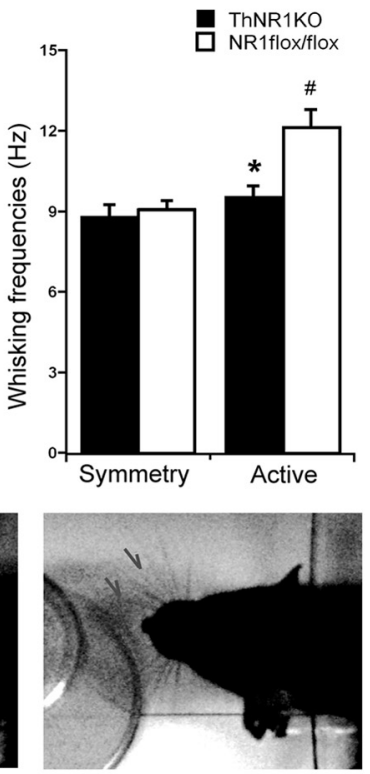

Active whisking
Tactile sensation test

Object recognition
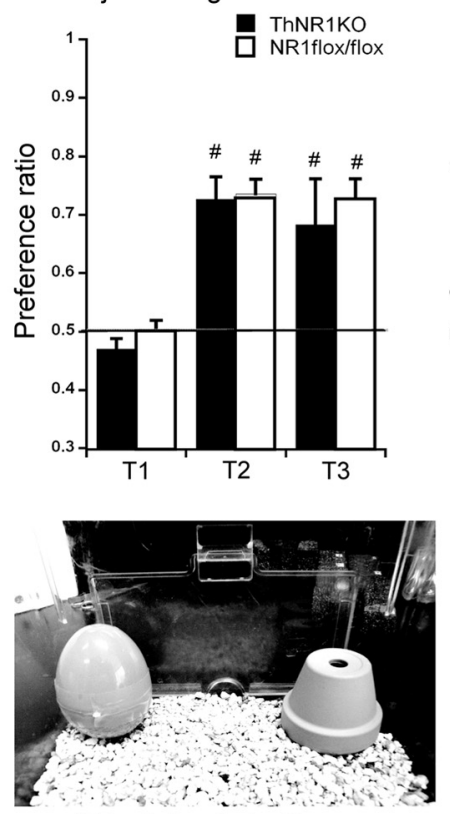

Object discrimination
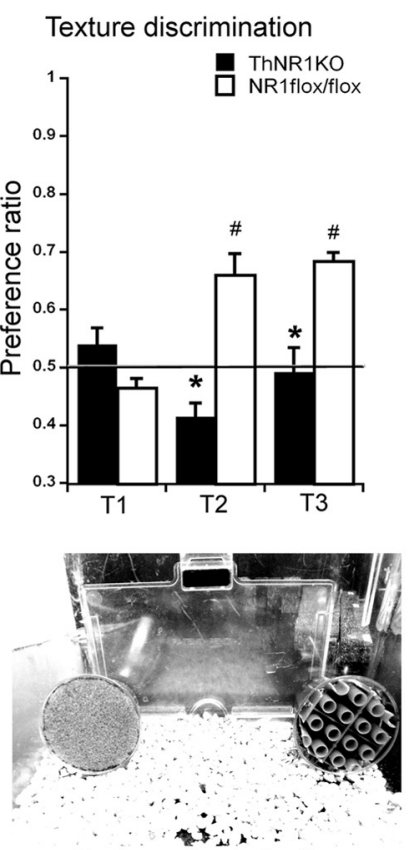

Texture discrimination

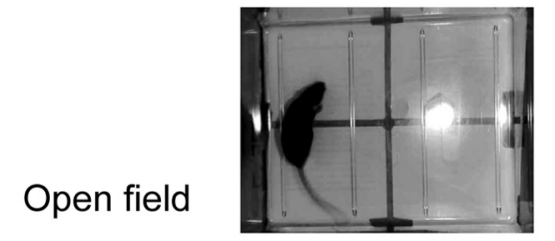

Locomotion

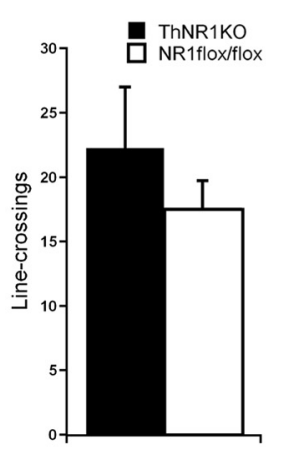

Risk assessment

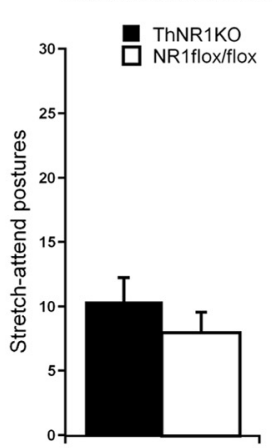

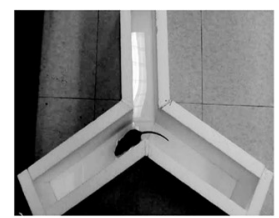

Y-maze

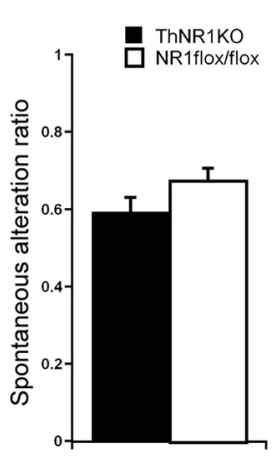

\section{Social behavior}

Social contact

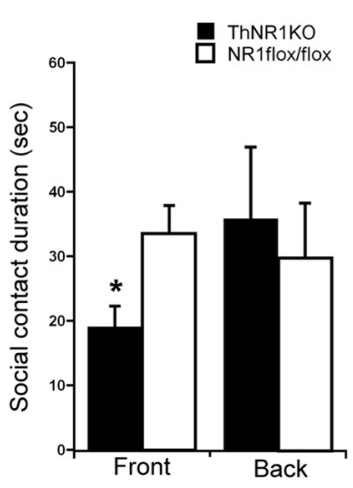

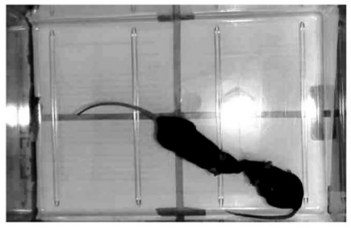

Flight response ThNR1KO

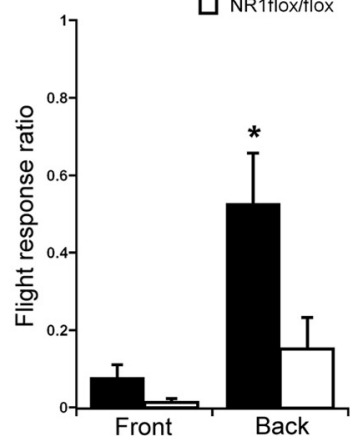

Figure 8. Whisking and tactile sensation are impaired in ThNR1KO mice. ThNR1KO mice show lower ratio of active whisking when the whiskers contact an object compared with control $\left(N R 1^{\text {flox fflox }}\right)$ mice $\left(t_{(14)}=6.2515, p<0.001\right)$. This ratio was calculated by the number of active whisking observed during the total whisker contacts with an object (at least 10 events for each mouse). ThNR1KO mice display similar frequencies of whisker vibration during symmetry whisking, but lower frequencies during active whisking compared with controls (two-way ANOVA: strain $F_{(1,27)}=6.976, p=0.0136$; trial $F_{(1,27)}=0.646, p=0.4287$; and strain $\times$ trial $\left.F_{(1,27)}=5.079, p=0.0325\right)$. In the object-recognition test, there were no significant differences between the knock-out and control groups throughout trials. However, the preference ratios on Trials 2 and 3 were higher than Trial 1 (two-way ANOVA: $\operatorname{strain} F_{(1,14)}=0.880, p=0.3641$; trial $F_{(2,28)}=20.509$, $p<0.001$; and strain $\left.\times \operatorname{trial} F_{(2,28)}=0.099, p=0.9062\right)$. In the texture-discrimination test, ThNR7K0 mice show significantly lower preference than controls on Trials 2 and 3 but not on Trial 1 (two-way ANOVA: strain $F_{(1,14)}=19.615, p=0.0006$; trial $F_{(2,28)}=5.258, p=0.0115$; and strain $\times$ trial $\left.F_{(2,28)}=20.628, p<0.0001\right)$. In the open-field test, there were no significant differences in locomotion $\left(t_{(10)}=0.89204, p=0.3933\right)$ or risk assessment $\left(t_{(14)}=0.9876, p=0.3401\right)$. In the Y-maze (spatial ability), there was no group difference in spontaneous alteration $\left(t_{(14)}=1.6723\right.$, $p=0.1166)$. However, in the social behavior test, ThNR1K0 mice display lower contacts toward the front of the opponent $\left(t_{(14)}=2.5903, p=0.021\right)$, while similar contacts toward the back of the opponent $\left(t_{(14)}=0.4318, p=0.6725\right)$. ThNR1K0 mice also show higher flight response ratio when approached by another mouse from the back $\left(t_{(14)}=2.492, p=0.0259\right)$, but not so much when approached from the front $\left(t_{(8)}=1.9151, p=0.0918\right)$.

projection of trigeminal afferents and gross brain morphology appeared normal. NMDAR signaling is important in patterning of neural connections along the rodent somatosensory pathway (Li et al., 1994; Kutsuwada et al., 1996; Iwasato et al., 1997, 2000; Rudhard et al., 2003).
Here, we asked the question that if NMDAR function is selectively disrupted in thalamic VB neurons, which lie between the brainstem and the cortex, can the PrV afferents form patterns in the VB and VB cells convey them to the cortex? In ThNR1KO mice, the presence of barrelettes but absence of barreloids in the 
VB and as a consequence absence of barrels in the SI cortex was predicted. Patterning of TCA terminals, corresponding to large caudal whiskers, was unexpected. When lemniscal axons do not form patterns in the VB and VB neurons do not form barreloids, how some TCAs still form any patterning in the cortex remains unresolved. A weak patterning corresponding to the large whiskers in CxNR1KO mice was also noted (Iwasato et al., 2000). It is possible that non-NMDAR-mediated mechanisms, perhaps the fast AMPA component of the thalamocortical transmission, also participate in terminal patterning of TCAs that correspond to large caudal whiskers. Perhaps, if total NR1KO mice (Li et al., 1994) were to live longer a weak TCA patterning could be discerned in the cortex, albeit absence of any patterning in the brainstem.

Postsynaptic NMDARs play a major role in dendritic orientation of pattern-forming cells in the brainstem and in the barrel cortex (Datwani et al., 2002; Lee et al., 2005b; Mizuno et al., 2014). A recent study showed that $\mathrm{BTB} / \mathrm{POZ}$ domain-containing 3 (BTBD3) translocates to the cell nucleus in an activity (NMDAR)-dependent manner and controls dendritic orientation of layer 4 cells toward active patches of TCA terminals during development (Matsui et al., 2013). Ectopic expression of Btbd3 can also direct stellate cell dendrites toward active axon terminals in the mouse visual cortex or when expressed in the ferret visual cortex (Matsui et al., 2013).

The impact of neurotransmitter release on barrel formation was analyzed in RIM-DKO ${ }^{\text {Sert }}$ mice, which lack thalamic RIM1 and RIM2 proteins (Narboux-Nême et al., 2012). A reduction of thalamocortical neurotransmission efficacy by $67 \%$ led to a barrelless phenotype with relatively normal patterning of TCAs. Phenotype of thalamus-specific VGLUT1 and 2 double knockout mice further underscored the role of efficient presynaptic activity in pattern formation and even cortical lamina-specific, cell-type differentiation in the barrel cortex (Li et al., 2013).

We found that thalamocortical transmission of whiskerrelated information is substantially impaired in ThNR1KO mice. In the absence of NMDAR-mediated postsynaptic response, the duration of excitatory response of VB neurons was much shorter. As reported before for the CxNR1KO barrel cells (Lo et al., 2013), the shortened EPSPs impede synaptic transmission of (slowly adapting) signals. Present results from the ThNR1KO VB also present a similar scenario. In the rodent $\mathrm{VB}, 37 \%$ thalamocortical projection neurons are slowly adapting with an average firing rate of $\sim 24$ spikes per second (Simons and Carvell, 1989). In the trigeminal ganglion cells, tonic responses represent amplitude of whisker deflection (Shoykhet et al., 2000; Stüttgen et al., 2006). Thus, the whisker-related information encoded by tonic responses cannot faithfully reach the barrel cortex in ThNR1KO mice. The low Pr of TCA terminals of ThNR1KO mice further weakens the synaptic transmission from VB to the barrel cortex.

Presynaptic NMDARs are present in the cerebral cortex and are proposed to increase glutamate-release probability (Brasier and Feldman, 2008; Rodríguez-Moreno et al., 2010; Duguid, 2013). In ThNR1KO mice, since VB cells lack functional NMDARs, it is reasonable to assume that presynaptic NMDARs are also absent in TCA terminals, subsequently contributing to the decreased Pr. The reduction of the released transmitter from TCAs would make it difficult to induce postsynaptic spikes during whisker deflection. Voltage-sensitive dye imaging experiments also support this interpretation. Deflection of a single whisker evoked a much weaker barrel cortex activity, albeit roughly topographical. Most likely the precision and intensity of whisker-evoked signals are blurred in the diencephalon.
To what extent does the absence of whisker- and paw-related patterns in the thalamus, and as a consequence in the cortex, affect the behavior of the animal? We are not aware of any behavioral tests for VB function alone. Further, any cellular or molecular disruption confined to VB will also affect the downstream target the neocortex. Nonetheless, we tested the ThNR1KO mice in a variety of behavioral tasks, most involving whisker-related sensory processing.

Whiskers are essential for a variety of tasks, such as gap distance and cliff assessment, spatial perception, object localization, and shape and texture discrimination (Schiffman et al., 1970; Hutson and Masterton, 1986; Carvell and Simons, 1995; Krupa et al., 2004; Ahissar and Knutsen, 2008; O'Connor et al., 2010; Kleinfeld and Deschênes, 2011; Deschênes et al., 2012). Whiskers are also involved in social behaviors, e.g., huddling (Landers and Sullivan, 1999) whisker "barbering" (Sarna et al., 2000). We did not note impairment in general motor abilities of the ThNR1KO mice; both the whisker and paw sensation-dependent behavioral performances were poor relative to control mice.

Testing for cognitive and social behaviors did not reveal deficits in spatial memory or locomotion and risk assessment in an open field. However, in social behaviors mutant mice spent less time contacting a conspecific and showed increased flight response when contacted by another mouse. These observations suggest that impaired whisker sensation, along the thalamocortical segment of the ascending trigeminal and dorsal column lemniscal system, may account for altered social behaviors.

An important caveat to the studies and interpretations presented here is that since we used 5-HTTCre, recombination was not exclusively restricted to the VB and other sensory thalamic nuclei but was also present in the serotonergic raphé nuclei and to a lesser degree in the cingulate cortex. The cingulate cortex does not have any known direct connections with the whisker-barrel neuraxis, but the raphé serotonergic system does. Serotonergic "modulatory" projections to the VB or the barrel cortex may also play a role in the pattern and behavioral phenotypes we observed. We do not think that this possibility is likely for a number of reasons. First, although there are serotonergic projections from the raphé nuclei to the brainstem trigeminal nuclei, whiskerspecific patterning was not affected in the brainstem of ThNR1KO mice. Second, barrel pattern deficits related to 5-HT have been shown only in mice that have excess 5-HT in the neocortex as a consequence of a lack of 5-HT degrading enzyme monoamine oxidase A (MAOA) or in 5-HTT knock-out mice (Cases et al., 1996; Persico et al., 2001). In both cases, pharmacological or genetic blockade of 5-HT signaling restored barrel formation (Cases et al., 1996; Persico et al., 2001; Rebsam et al., 2002, 2005). It appears that 5-HT excess, rather than deficiency, disrupts barrel formation in MAOA knock-outs, and loss of 5HTT in TCAs rather than in raphé axons is responsible for pattern deficits seen in 5HTT knock-out mice. Finally, Pet ${ }^{\text {cre }} /$ Lmx $1 b^{\text {flox }}$ mice, which lack all serotonergic neurons, develop barrelettes in the brainstem, barreloids in the VB, and barrels in the cortex (R.S. Erzurumlu, unpublished results). Thus, it is reasonable to conclude that thalamic and cortical pattern deficits in ThNR1KO mice are due to loss of NMDAR function in the VB rather than in the raphé nuclei.

At the present time we do not know how impaired NMDAR function in serotonergic neurons might impact their modulatory activity of other circuits. Pet ${ }^{\text {cre }} / \mathrm{Lmx} 1 \mathrm{~b}^{\text {flox }}$ mice reportedly show differential pain sensitivity but exhibit normal locomotor activity (Zhao et al., 2006, 2007). In another mouse model with conditional vesicular monoamine transporter 2 gene deletion, increase 
in escape-like reactions in response to tail suspension and anxiety responses were found without notable locomotor deficiencies (Narboux-Nême et al., 2011). Pharmacological lowering of serotonin levels in mice did not change the behavior of mice in the forced swim test or tail suspension test (van Donkelaar et al., 2010; Poleszak et al., 2011). These studies, which focus on loss of serotonin or significant reduction in brain 5-HT levels, do not suggest potential confounding effects in our behavioral results and interpretations, but we cannot discount the possibility that several of the behavioral deficits we observed may have resulted from a combination of sensory thalamus and raphé serotonergic system NMDAR impairment.

\section{References}

Agmon A, Connors BW (1992) Correlation between intrinsic firing patterns and thalamocortical synaptic responses of neurons in mouse barrel cortex. J Neurosci 12:319-329. Medline

Ahissar E, Knutsen PM (2008) Object localization with whiskers. Biol Cybern 98: 449-458. CrossRef Medline

Arsenault D, Zhang ZW (2006) Developmental remodelling of the lemniscal synapse in the ventral basal thalamus of the mouse. J Physiol 573:121132. CrossRef Medline

Barnéoud P, Gyger M, Andrés F, van der Loos H (1991) Vibrissa-related behavior in mice: transient effect of ablation of the barrel cortex. Behav Brain Res 44:87-99. CrossRef Medline

Brasier DJ, Feldman DE (2008) Synapse-specific expression of functional presynaptic NMDA receptors in rat somatosensory cortex. J Neurosci 28:2199-2211. CrossRef Medline

Carvell GE, Simons DJ (1990) Biometric analyses of vibrissal tactile discrimination in the rat. J Neurosci 10:2638-2648. Medline

Carvell GE, Simons DJ (1995) Task- and subject-related differences in sensorimotor behavior during active touch. Somatosens Mot Res 12:1-9. CrossRef Medline

Cases O, Vitalis T, Seif I, De Maeyer E, Sotelo C, Gaspar P (1996) Lack of barrels in the somatosensory cortex of monoamine oxidase A-deficient mice: role of a serotonin excess during the critical period. Neuron 16:297307. CrossRef Medline

Castro-Alamancos MA (2002) Properties of primary sensory (lemniscal) synapses in the ventrobasal thalamus and the relay of high-frequency sensory inputs. J Neurophysiol 87:946-953. Medline

Cummings BJ, Engesser-Cesar C, Cadena G, Anderson AJ (2007) Adaptation of a ladder beam walking task to assess locomotor recovery in mice following spinal cord injury. Behav Brain Res 177:232-241. CrossRef Medline

Datwani A, Iwasato T, Itohara S, Erzurumlu RS (2002) NMDA receptordependent pattern transfer from afferents to postsynaptic cells and dendritic differentiation in the barrel cortex. Mol Cell Neurosci 21:477-492. CrossRef Medline

Deschênes M, Moore J, Kleinfeld D (2012) Sniffing and whisking in rodents. Curr Opin Neurobiol 22:243-250. CrossRef Medline

Duguid IC (2013) Presynaptic NMDA receptors: are they dendritic receptors in disguise? Brain Res Bull 93:4-9. CrossRef Medline

Erzurumlu RS, Gaspar P (2012) Development and critical period plasticity of the barrel cortex. Eur J Neurosci 35:1540-1553. CrossRef Medline

Erzurumlu RS, Iwasato T (2006) Patterning of the somatosensory maps with NMDA receptors. In: Development and plasticity in sensory thalamus and cortex (Erzurumlu RS, Guido W, Molnar Z eds) pp 158-182. New York: Springer.

Erzurumlu RS, Kind PC (2001) Neural activity: sculptor of 'barrels' in the neocortex. Trends Neurosci 24:589-595. CrossRef Medline

Espinosa JS, Wheeler DG, Tsien RW, Luo L (2009) Uncoupling dendrite growth and patterning: single-cell knockout analysis of NMDA receptor 2B. Neuron 62:205-217. CrossRef Medline

Ferezou I, Bolea S, Petersen CC (2006) Visualizing the cortical representation of whisker touch: voltage-sensitive dye imaging in freely moving mice. Neuron 50:617-629. CrossRef Medline

Gerlai R, Thibodeaux H, Palmer JT, van Lookeren Campagne M, Van Bruggen N (2000) Transient focal cerebral ischemia induces sensorimotor deficits in mice. Behav Brain Res 108:63-71. CrossRef Medline

Hutson KA, Masterton RB (1986) The sensory contribution of a single vibrissa's cortical barrel. J Neurophysiol 56:1196-1223. Medline
Iwasato T, Erzurumlu RS, Huerta PT, Chen DF, Sasaoka T, Ulupinar E, Tonegawa S (1997) NMDA receptor-dependent refinement of somatotopic maps. Neuron 19:1201-1210. CrossRef Medline

Iwasato T, Datwani A, Wolf AM, Nishiyama H, Taguchi Y, Tonegawa S, Knöpfel T, Erzurumlu RS, Itohara S (2000) Cortex-restricted disruption of NMDAR1 impairs neuronal patterns in the barrel cortex. Nature 406: 726-731. CrossRef Medline

Iwasato T, Katoh H, Nishimaru H, Ishikawa Y, Inoue H, Saito YM, Ando R, Iwama M, Takahashi R, Negishi M, Itohara S (2007) Rac-GAP alphachimerin regulates motor-circuit formation as a key mediator of EphrinB3/EphA4 forward signaling. Cell 130:742-753. CrossRef Medline

Kivrak BG, Erzurumlu RS (2013) Development of the principal nucleus trigeminal lemniscal projections in the mouse. J Comp Neurol 521:299311. CrossRef Medline

Kleinfeld D, Deschênes M (2011) Neuronal basis for object location in the vibrissa scanning sensorimotor system. Neuron 72:455-468. CrossRef Medline

Kobayashi Y, Sano Y, Vannoni E, Goto H, Suzuki H, Oba A, Kawasaki H, Kanba S, Lipp HP, Murphy NP, Wolfer DP, Itohara S (2013) Genetic dissection of medial habenula-interpeduncular nucleus pathway function in mice. Front Behav Neurosci 7:17. CrossRef Medline

Krupa DJ, Wiest MC, Shuler MG, Laubach M, Nicolelis MA (2004) Layerspecific somatosensory cortical activation during active tactile discrimination. Science 304:1989-1992. CrossRef Medline

Kutsuwada T, Sakimura K, Manabe T, Takayama C, Katakura N, Kushiya E, Natsume R, Watanabe M, Inoue Y, Yagi T, Aizawa S, Arakawa M, Takahashi T, Nakamura Y, Mori H, Mishina M (1996) Impairment of suckling response, trigeminal neuronal pattern formation, and hippocampal LTD in NMDA receptor epsilon 2 subunit mutant mice. Neuron 16:333344. CrossRef Medline

Landers MS, Sullivan RM (1999) Vibrissae-evoked behavior and conditioning before functional ontogeny of the somatosensory vibrissae cortex. J Neurosci 19:5131-5137. Medline

Landers M, Philip Zeigler H (2006) Development of rodent whisking: trigeminal input and central pattern generation. Somatosens Mot Res 23:1-10. CrossRef Medline

Lebrand C, Cases O, Wehrlé R, Blakely RD, Edwards RH, Gaspar P (1998) Transient developmental expression of monoamine transporters in the rodent forebrain. J Comp Neurol 401:506-524. CrossRef Medline

Lee LJ, Erzurumlu RS (2005) Altered parcellation of neocortical somatosensory maps in N-methyl-D-aspartate receptor-deficient mice. J Comp Neurol 485:57-63. CrossRef Medline

Lee LJ, Iwasato T, Itohara S, Erzurumlu RS (2005a) Exuberant thalamocortical axon arborization in cortex-specific NMDAR1 knockout mice. J Comp Neurol 485:280-292. CrossRef Medline

Lee LJ, Lo FS, Erzurumlu RS (2005b) NMDA receptor-dependent regulation of axonal and dendritic branching. J Neurosci 25:2304-2311. CrossRef Medline

Li H, Fertuzinhos S, Mohns E, Hnasko TS, Verhage M, Edwards R, Sestan N, Crair MC (2013) Laminar and columnar development of barrel cortex relies on thalamocortical neurotransmission. Neuron 79:970-986. CrossRef Medline

Li Y, Erzurumlu RS, Chen C, Jhaveri S, Tonegawa S (1994) Whisker-related neuronal patterns fail to develop in the trigeminal brainstem nuclei of NMDAR1 knockout mice. Cell 76:427-437. CrossRef Medline

Liu XB, Murray KD, Jones EG (2004) Switching of NMDA receptor 2A and $2 \mathrm{~B}$ subunits at thalamic and cortical synapses during early postnatal development. J Neurosci 24:8885-8895. CrossRef Medline

Lo FS, Akkentli F, Tsytsarev V, Erzurumlu RS (2013) Functional significance of cortical NMDA receptors in somatosensory information processing. J Neurophysiol 110:2627-2636. CrossRef Medline

Matsui A, Tran M, Yoshida AC, Kikuchi SS, U M, Ogawa M, Shimogori T (2013) BTBD3 controls dendrite orientation toward active axons in mammalian neocortex. Science 342:1114-1118. CrossRef Medline

Mizuno H, Luo W, Tarusawa E, Saito YM, Sato T, Yoshimura Y, Itohara S, Iwasato T (2014) NMDAR-regulated dynamics of layer 4 neuronal dendrites during thalamocortical reorganization in neonates. Neuron 82 : 365-379. CrossRef Medline

Narboux-Nême N, Pavone LM, Avallone L, Zhuang X, Gaspar P (2008) Serotonin transporter transgenic (SERTcre) mouse line reveals developmental targets of serotonin specific reuptake inhibitors (SSRIs). Neuropharmacology 55:994-1005. CrossRef Medline 
Narboux-Nême N, Sagné C, Doly S, Diaz SL, Martin CB, Angenard G, Martres MP, Giros B, Hamon M, Lanfumey L, Gaspar P, Mongeau R (2011) Severe serotonin depletion after conditional deletion of the vesicular monoamine transporter 2 gene in serotonin neurons: neural and behavioral consequences. Neuropsychopharmacology 36:2538-2550. CrossRef Medline

Narboux-Nême N, Evrard A, Ferezou I, Erzurumlu RS, Kaeser PS, Lainé J, Rossier J, Ropert N, Südhof TC, Gaspar P (2012) Neurotransmitter release at the thalamocortical synapse instructs barrel formation but not axon patterning in the somatosensory cortex. J Neurosci 32:6183-6196. CrossRef Medline

O'Connor DH, Peron SP, Huber D, Svoboda K (2010) Neural activity in barrel cortex underlying vibrissa-based object localization in mice. Neuron 67:1048-1061. CrossRef Medline

Persico AM, Mengual E, Moessner R, Hall FS, Revay RS, Sora I, Arellano J, DeFelipe J, Gimenez-Amaya JM, Conciatori M, Marino R, Baldi A, Cabib S, Pascucci T, Uhl GR, Murphy DL, Lesch KP, Keller F, Hall SF (2001) Barrel pattern formation requires serotonin uptake by thalamocortical afferents, and not vesicular monoamine release. J Neurosci 21:68626873. Medline

Poleszak E, Wlaź P, Szewczyk B, Wlaź A, Kasperek R, Wróbel A, Nowak G (2011) A complex interaction between glycine/NMDA receptors and serotonergic/noradrenergic antidepressants in the forced swim test in mice. J Neural Transm 118:1535-1546. CrossRef Medline

Rebsam A, Seif I, Gaspar P (2002) Refinement of thalamocortical arbors and emergence of barrel domains in the primary somatosensory cortex: a study of normal and monoamine oxidase a knock-out mice. J Neurosci 22:8541-8552. Medline

Rebsam A, Seif I, Gaspar P (2005) Dissociating barrel development and lesion-induced plasticity in the mouse somatosensory cortex. J Neurosci 25:706-710. CrossRef Medline

Rodríguez-Moreno A, Banerjee A, Paulsen O (2010) Presynaptic NMDA receptors and spike timing-dependent depression at cortical synapses. Front Synaptic Neurosci 2:18. CrossRef Medline

Rudhard Y, Kneussel M, Nassar MA, Rast GF, Annala AJ, Chen PE, Tigaret CM, Dean I, Roes J, Gibb AJ, Hunt SP, Schoepfer R (2003) Absence of Whisker-related pattern formation in mice with NMDA receptors lacking coincidence detection properties and calcium signaling. J Neurosci 23: 2323-2332. Medline

Ruthazer ES, Cline HT (2004) Insights into activity-dependent map formation from the retinotectal system: a middle-of-the-brain perspective. J Neurobiol 59:134-146. CrossRef Medline

Sakai K. Miyazaki JI (1997) A transgenic mouse line that retains Cre recombinase activity in mature oocytes irrespective of the cre transgene transmission. Biochem Biophys Res Commun 237:318-324. CrossRef Medline

Sarna JR, Dyck RH, Whishaw IQ (2000) The Dalila effect: C57BL6 mice barber whiskers by plucking. Behav Brain Res 108:39-45. CrossRef Medline

Sarnyai Z, Sibille EL, Pavlides C, Fenster RJ, McEwen BS, Toth M (2000)
Impaired hippocampal-dependent learning and functional abnormalities in the hippocampus in mice lacking serotonin(1A) receptors. Proc Natl Acad Sci U S A 97:14731-14736. CrossRef Medline

Schiffman HR, Lore R, Passafiume J, Neeb R (1970) Role of vibrissae for depth perception in the rat (Rattus norvegicus). Anim Behav 18:290-292. CrossRef Medline

Shoykhet M, Doherty D, Simons DJ (2000) Coding of deflection velocity and amplitude by whisker primary afferent neurons: implications for higher level processing. Somatosens Mot Res 17:171-180. CrossRef Medline

Simons DJ, Carvell GE (1989) Thalamocortical response transformation in the rat vibrissa/barrel system. J Neurophysiol 61:311-330. Medline

Stüttgen MC, Rüter J, Schwarz C (2006) Two psychophysical channels of whisker deflection in rats align with two neuronal classes of primary afferents. J Neurosci 26:7933-7941. CrossRef Medline

Suryavanshi PS, Ugale RR, Yilmazer-Hanke D, Stairs DJ, Dravid SM (2014) GluN2C/GluN2D subunit-selective NMDA receptor potentiator CIQ reverses MK-801-induced impairment in prepulse inhibition and working memory in Y-maze test in mice. Br J Pharmacol 171:799-809. CrossRef Medline

Tominaga T, Kajiwara R, Tominaga Y (2013) VSD imaging method of ex vivo brain preparation. J Neurosci Neuroeng 2:211-219.

Tsien JZ, Huerta PT, Tonegawa S (1996) The essential role of hippocampal CA1 NMDA receptor-dependent synaptic plasticity in spatial memory. Cell 87:1327-1338. CrossRef Medline

Tsytsarev V, Pope D, Pumbo E, Yablonskii A, Hofmann M (2010) Study of the cortical representation of whisker directional deflection using voltagesensitive dye optical imaging. Neuroimage 53:233-238. CrossRef Medline van Donkelaar EL, Blokland A, Lieben CK, Kenis G, Ferrington L, Kelly PA, Steinbusch HW, Prickaerts J (2010) Acute tryptophan depletion in C57BL/6 mice does not induce central serotonin reduction or affective behavioural changes. Neurochem Int 56:21-34. CrossRef Medline

Zhang ZW, Peterson M, Liu H (2013) Essential role of postsynaptic NMDA receptors in developmental refinement of excitatory synapses. Proc Natl Acad Sci U S A 110:1095-1100. CrossRef Medline

Zhao ZQ, Scott M, Chiechio S, Wang JS, Renner KJ, Gereau RW 4th, Johnson RL, Deneris ES, Chen ZF (2006) Lmxlb is required for maintenance of central serotonergic neurons and mice lacking central serotonergic system exhibit normal locomotor activity J Neurosci 26:12781-12788. CrossRef

Zhao ZQ, Chiechio S, Sun YG, Zhang KH, Zhao CS, Scott M, Johnson RL, Deneris ES, Renner KJ, Gereau RW 4th, Chen ZF (2007) Mice lacking central serotonergic neurons show enhanced inflammatory pain and an impaired analgesic response to antidepressant drugs J Neurosci 27:60456053. CrossRef

Zhuang X, Masson J, Gingrich JA, Rayport S, Hen R (2005) Targeted gene expression in dopamine and serotonin neurons of the mouse brain. J Neurosci Methods 143:27-32. CrossRef Medline 